\title{
Regulatory Restrictions Across U.S. Protein Supply Chains
}

\author{
Aaron J. Staples ${ }^{1}\left(\mathbb{D}\right.$, Dustin Chambers ${ }^{2}$, Richard T. Melstrom ${ }^{3}\left(\mathbb{O}\right.$ and Trey Malone ${ }^{1 \star}(\mathbb{D}$ \\ ${ }^{1}$ Department of Agricultural, Food, and Resource Economics, Michigan State University, East Lansing, MI, USA, ${ }^{2}$ Department \\ of Economics and Finance, Salisbury University, Salisbury, MD, USA and ${ }^{3}$ School of Environmental Sustainability, Loyola \\ University Chicago, Chicago, IL, USA \\ ${ }^{\star}$ Corresponding author. Email: tmalone@msu.edu
}

\begin{abstract}
Food regulations protect consumer health, mitigate environmental concerns, and promote animal welfare, but they can also hinder innovation, limit entrepreneurship, and generate higher consumer prices. This study examines the number of federal and state regulatory restrictions affecting the beef, pork, poultry, sheep, goat, and seafood industries, including processing, wholesale distribution, and retail sales. We also examine state regulatory heterogeneity associated with animal protein products. Our results suggest that protein supply chains have become subject to tens of thousands of regulatory constraints over the past half-century. We also find substantial heterogeneity in the number of state restrictions associated with animal production, indicative of large differences in the amount of administrative law across states. Results highlight that the patchwork approach of U.S. food policy creates overlapping, cumbersome guidelines for manufacturers, and given the interconnectivity of modern food supply chains, the framework can create additional hurdles for interstate commerce.
\end{abstract}

Keywords: animal agriculture; food regulation; protein supply chains; regulatory constraints

JEL classifications: L51; Q13; Q18

\section{Introduction}

Food safety, security, and resilience are the primary objectives of several key government agencies. At the federal level, the U.S. Food and Drug Administration (FDA), the U.S. Department of Agriculture Food Safety Inspection Service (USDA-FSIS), the Environmental Protection Agency (EPA), and Centers for Disease Control and Prevention (CDC) regulate and monitor food safety and production. At the state and local level, there are over 3,000 agencies whose main objective is regulation and oversight of food retail (FDA, 2020). Regulatory constraints-such as mandatory food labeling laws, safety and quality inspections, and establishment licensing-protect consumers, mitigate environmental hazards, and moderate industry and economic growth (Dawson and Seater, 2013), albeit at the risk of unintended consequences (Malone and Stack, 2017) and higher consumer prices (Chambers, Collins, and Krause, 2019).

In this article, we explore regulatory variation across supply chains at the federal and state level for animal protein products, including beef, pig, poultry, sheep, goat, and seafood. We focus on these foods because animal protein makes up nearly $50 \%$ of total protein intake in U.S. adults (Pasiakos et al., 2015), and nearly $80 \%$ of U.S. adults consume meat as a protein source while $30 \%$ consume seafood (Shahbandeh, 2018). Indeed, beef, poultry, and seafood are among the most-consumed protein sources in the United States (USDA-ERS, 2019). Supply chain sustainability and resiliency have been brought to center stage given meat shortages partially driven by

(C) The Author(s), 2021. Published by Cambridge University Press on behalf of the Southern Agricultural Economics Association. This is an Open Access article, distributed under the terms of the Creative Commons Attribution licence (https://creativecommons.org/licenses/by/4.0/), which permits unrestricted re-use, distribution, and reproduction in any medium, provided the original work is properly cited. 
COVID-19 outbreaks at meat-packing plants (Lusk, Tonsor, and Schulz, 2021; Mallory, 2021; Martinez, Maples, and Benavidez, 2021), environmental concerns linking meat consumption to climate change (Hunter and Röös, 2016), and increased consumer sentiment for animal welfare (McKendree, Croney, and Widmar, 2014; Ortega and Wolf, 2018). Indeed, relaxing regulatory restrictions on agricultural systems has been one recommendation for increasing supply chain resiliency (Malone, Schaefer, and Lusk, 2021; Thilmany and Malone, 2020). As such, our objective in this article is to compare regulatory restrictions across animal producer types and industry supply chains.

Many studies examine the effects of regulations in the food sector (Bovay and Alston, 2018; Escalante, Luo, and Taylor, 2020; Mojduszka and Caswell, 2000; Zago \& Pick, 2004), but few have explored regulations within an industry across states or across whole supply chains as we do here. Fewer still have sought to compare regulatory constraints between industries (Al-Ubaydli and McLaughlin, 2017). To accomplish these tasks, we utilize novel data made available from the Mercatus Center's RegData and State RegData. These databases utilize machine-learning techniques to count instances of words that indicate binding restrictions in federal and state laws. We use these counts and input-output (I-O) modeling to assess the number of regulatory restrictions at the federal level affecting animal producers, as well as the number of federal and state regulatory restrictions affecting animal protein supply chains.

Our contribution to the literature is threefold. First, we complement existing research (AlUbaydli and McLaughlin, 2017; Dawson and Seater, 2013; Djankov et al., 2002; Stigler, 1971) by examining the number of federal regulatory restrictions affecting the beef, pig, poultry, sheep, goat, and seafood industries, which reveals the potential for important differences in U.S. animal production regulations. Comparisons across industries allows us to assess calls to reduce regulatory costs in certain industries, for example, aquaculture in the United States (Engle et al., 2019). ${ }^{1}$ If regulatory restrictions closely approximate regulatory burden, then one would expect that industries with greater relative concerns about regulatory burden have more regulatory restrictions. ${ }^{2}$ Second, we examine the number of regulatory restrictions at the federal level "downstream" of animal producers, including processing, wholesale distribution, and retail sales, to assess the amount of regulation across agricultural supply chains and animal protein sources. Examining regulations across an entire supply chain is important because regulation directed at one part of the chain can affect activity in another part. Third, we examine state regulatory heterogeneity associated with animal protein products by measuring the number of restrictions at the state level. We examine this heterogeneity for animal producers as a whole, without disaggregating by animal type, because of insufficient granularity in the data at the state level. Nevertheless, these results reveal stark differences in the amount of restrictions by state.

In making these contributions, we also seek to introduce a novel dataset to the agricultural economics literature. The restriction counts in RegData offer a number of advantages over other, previously used metrics quantifying regulation at the macrolevel. For example, prior research has used pages published in the Federal Register to proxy regulations, except the Federal Register includes parts that actually remove regulations and thus make it a poor measure (Al-Ubaydli and McLaughlin, 2017). Other metrics include the size of a statute document or the number

\footnotetext{
${ }^{1}$ This particular example is important because increasing U.S. reliance on imports to meet domestic seafood demand has led to concerns among industry stakeholders and policy makers that U.S. aquaculture faces disproportionate barriers to growth (Hyink and Melstrom, 2021). Between 1950 and 2017, U.S. aquaculture production as a share of global output fell from $10 \%$ to less than 0.5\% (Shamshak et al., 2019), which appears to lend some credibility to these concerns. However, it should also be noted that U.S. aquaculture output in fact nearly tripled between 1980 and 2017 from 168,000 tonnes to 468,000 tonnes, with production peaking in 2004 at over 600,000 tonnes (FAO, 2021a). In contrast, between 1970 and 2018 U.S. beef production increased 25\% (USDAERS, 2021), and between 1960 and 2006 U.S. broiler production increased nearly 500\% (MacDonald, 2008).

${ }^{2}$ The Government Accountability Office (GAO) identifies three basic measures of regulatory burden: indicators (e.g. pages in the Code of Federal Regulations), time (e.g. hours to complete paperwork), and cost (GAO, 1996). For the purposes of this paper, we use burden and cost as synonyms.
} 
of federal employees assigned to regulatory activities (GAO, 1996). Another key advantage to RegData is that the restrictions are an annual, industry-specific panel, which makes it possible to track the accumulation of regulations across industries. In contrast, prior research has tended to rely on cross-sectional proxies (Al-Ubaydli and McLaughlin, 2017). RegData covers the Code of Federal Regulations (CFR) from 1970 to 2019, so we can use the restriction counts to assess relative changes in animal protein industry regulations over nearly a half century.

The remainder of this article is structured as follows. In Section 2, we provide background on food regulations and the CFR. Section 3 introduces the methodology used to quantify regulatory restrictions across supply chains. In Section 4, we present the results, and Section 5 discusses these results. Section 6 concludes.

\section{Background}

From the onset of U.S. food safety standards and regulations, most meat products have been regulated differently than other food products. The first major federal food policy initiatives were the Pure Food and Drug Act of 1906 and the Meat Inspection Act of 1906. Whereas the Pure Food and Drug Act established the U.S. Food and Drug Administration (FDA) and gave the agency overarching authority to regulate food products, the Federal Meat Inspection Act-signed into law the same day - gave the USDA the jurisdiction to inspect cattle, hog, poultry, sheep, and goat slaughtering and processing (Fortin, 2017).

Advancements in refrigeration technology shifted consumption patterns and raised the standard of living in the United States, leaving the Pure Food and Drug Act obsolete shortly after it was passed. In 1938, Congress passed the Food, Drug, and Cosmetic Act (FD\&C Act) of 1938, which still serves as the foundation for food law. The FD\&C Act has been amended over 100 times since it was passed in 1938 (Fortin, 2017), with the most significant amendment being the Food Safety Modernization Act (FSMA) of 2011. The FSMA offered seven substantial changes to the FD\&C Act of 1938, including measures to prevent foodborne outbreaks, subdue intentional adulteration of food products, and improve sanitary transportation requirements (Strauss, 2011; Thatte, 2019). Other significant amendments to the FD\&C Act include the Food Additive Amendment of 1958, the Color Additive Amendment of 1960, and the Nutritional Labeling and Education Act of 1990 (Fortin, 2017).

The Federal Meat Inspection Act of 1906 has also been amended significantly. Most notably, the Wholesome Meat Act of 1967 was introduced to prevent the adulteration and misbranding of meat products and to ensure the slaughter and processing of meat and meat products occurred in sanitary conditions (Fortin, 2017). Additional food policies governing the regulation of the meat industry include the Poultry Products Inspection Act of 1957, the Egg Products Inspection Act of 1970, and the Humane Methods of Livestock Slaughter Act of 1978 (USDA-FSIS, 2016).

Importantly, while most cattle, hog, poultry, egg, sheep, and goat products are regulated by the USDA-FSIS, aquaculture and seafood fall predominantly under the FDA's jurisdiction; and the FDA is currently a sub-division of the Department of Health and Human Services (HHS) not the USDA-FSIS. Thus, while the overarching goals of the FDA and USDA-FSIS are nearly identical, aquaculture is subject to different regulations than most other protein sources. In other words, amendments made to the FD\&C Act affect the aquaculture industry, but do not directly restrict the other meat industries, for which amendments must be made to the USDA-FSIS policies (e.g., Federal Meat Inspection Act). In addition, the regulatory jurisdiction does not always fall entirely on one agency. Indeed, the overlapping framework may be intentional, mitigating regulatory loopholes and capturing the decentralized expertise amongst various agencies. For example, in addition to regulation from the FDA under the Department of HHS, the aquaculture industry is regulated by the USDA, the EPA, the National Oceanic and Atmospheric Administration (NOAA), the U.S. Fisheries and Wildlife Service (FWS), the Animal and Plant Health Inspection Service (APHIS), and others (FAO, 2021b). 
It is also critical to summarize how statutes passed by Congress and signed into law by the President are converted into the regulations. When federal policy is signed into law, the statutes are codified into the United States Code. These statutes are then announced as regulations, subject to the interpretation of the federal agency with presiding jurisdiction. These regulations must then be codified into the CFR. However, prior to final publication of the regulations, an initial ruling is published in the Federal Register. The initial ruling outlines the agency's interpretation of the statute and describes the rules, protocols, and procedures for compliance. Once the initial ruling is posted, industry stakeholders and the general public are given notice of the proposed regulations. There is then a period for comment and clarification, after which the initial ruling is revised. Following revisions, the final ruling is published, an effective date is declared, and the regulation is officially codified in the CFR. Thus, while the statutes receive significant media attention when they are signed into law, codifying the regulations enforcing these statutes into the CFR can take several years.

In addition to federal laws enacted by Congress and the regulations authorized by these administrative agencies, states can legislate food policy. This authority is generally granted under the police powers provided to states by the Federalist system (Fortin, 2017), which ensures states are allowed to enact legislation to protect consumer health and welfare. However, state laws may be deemed unconstitutional if they interfere with interstate commerce, an authority given to the federal government (Sumner, 2017). In other words, if the state policy is shown to affect the production, distribution, or market prices outside of the state, the policy could be struck down by the courts (Fortin, 2017). Legal battles over policies such as California's Assembly Bill 1437 for cage-free eggs (Carter, Schaefer, and Scheitrum, 2021) and Vermont's call for mandatory labeling on genetically engineered food (Kolodinsky and Lusk, 2018) have reinvigorated the discussion surrounding the Commerce Clause. Nonetheless, since states have the ability to enact legislation on health, safety, and consumer welfare as it relates to food, food regulations are likely to vary across state borders.

The federal policies regulating food systems are complex and interconnected in an effort to protect the consumer and prevent regulatory loopholes. Further, state and local governments may regulate food systems more stringently than the federal government. Thus, there is significant merit in understanding the evolution of regulations as they pertain to food systems, comparing regulations across different supply chains, and examining the heterogeneity in regulations at the state level.

\section{Data and Methods}

We measure regulatory restrictions as the accumulation of words in federal and state law that indicate restrictions and requirements in a particular industry. Within the scope of our analysis, these "regulatory restrictions" come from two datasets of industry-specific regulations produced by the Mercatus Center: State RegData 2.0, and RegData 3.2. State RegData 2.0 counts each instance of a binding restriction that appears in the published rules and guidelines contained in the laws of 43 states plus the District of Columbia. RegData 3.2 is very similar, except that it counts each instance of a binding federal restriction that appears in the U.S. CFR. Each time a word indicating a restriction or requirement appears in the regulatory text (i.e. the words shall, must, may not, prohibited, and required), that word is counted as a regulatory restriction. RegData 3.2 also contains an index of restrictions at the four-digit North American Industry Classification System (NAICS) level, constructed by multiplying the number of restrictive words by a measure of industry relevance. Industry relevance is itself measured using a machine-learning algorithm trained on industry-specific publications in the Federal Register, which includes documents labeled with the relevant NAICS code and a writing style similar to the CFR. The algorithm identifies words, phrases, and other document features most closely associated with an industry's NAICS code or name, which helps determine when a unit of text is relevant to an industry. 
The association between a NAICS industry and document features is modeled using a logistic function. When applied to the CFR, this function calculates the probability that a federal law is relevant to a NAICS industry. Regulatory restrictions are thus probability-weighted by their industry relevance and summed by industry. For further details on the methodology of calculating restrictions and industry relevance, see McLaughlin \& Sherouse (2019).

The restriction counts in RegData offer a number of advantages over previously used metrics quantifying regulation at the macro level such as counting the total number of pages published in the Federal Register to proxy regulations, examining the size of a statute document, or calculating the number of federal employees assigned to regulatory activities (Al-Ubaydli and McLaughlin, 2017; GAO, 1996). Further, RegData provides an annual, industry-specific panel rather than a cross-sectional proxy, allowing researchers to track the accumulation of regulations across industries. RegData covers the CFR from 1970 to 2019, so we can use the restriction counts to assess relative changes in animal protein industry regulations over the past half-century.

Using RegData, we examine the accumulation of federal regulatory restrictions down the animal production industry's value chain. We mean "downstream" in the sense that processed animal protein is an intermediate input that increases in value (as measured by wholesale and retail margins) as it moves through the value chain from the rancher or farmer to the consumer. We refer to the restrictions associated with these activities as direct restrictions.

We calculate direct restrictions at the federal level in six animal protein industries: cattle ranching and farming, hog and pig farming, chicken and egg production, sheep and goat farming, aquaculture, and other animal production. These industries correspond to NAICS codes 1121, 1122, $1123,1124,1125$, and 1129 , respectively. We then calculate direct restrictions in the animal processing, wholesale distribution, and retail sales industries, which correspond to NAICS codes $311 \mathrm{X}$ (which includes sectors 3116 and 3117), 4244 and 4451, and through which most animal protein products pass before reaching consumers. This is similar to the approach of Malone and Chambers (2017), who measured federal regulatory restrictions that apply to both the three-tier beer distribution system (i.e., brewing, wholesale distribution, and retail distribution). In a followup study using a similar methodology, Staples et al. (2021) extended this analysis to the regulations promulgated by individual states, using State RegData to measure state regulatory restrictions that apply to both the beer value chain and the inputs needed to produce these goods and services. ${ }^{3}$ This article expands on this methodology to study regulations in animal protein production, counting direct restrictions across four-tier animal protein distribution systems (i.e. production, processing, wholesale distribution, and retail sales).

It is also possible to use RegData to estimate the "upstream" regulations that apply to an industry's supply chain. We refer to these as indirect restrictions because they affect inputs to animal production rather the animal producers or processors themselves. Following Chambers et al. (2019), ${ }^{4}$ Malone and Chambers (2017), and Staples et al. (2021), we calculate upstream regulations using I-O commodity weights from the Bureau of Economic Analysis (BEA) to weight the regulatory restrictions that apply to each industry that produces the inputs required by that industry's supply chain. Specifically,

$$
\operatorname{Reg}_{j, t}^{\text {indirect }}=\sum_{i} \alpha_{i} \cdot \operatorname{Reg}_{i, t}^{\text {direct }}
$$

estimates the total indirect federal restrictions that apply to industry $j$ (i.e., animal protein production, processing, wholesale or retail distribution) in year $t ; i$ is the index of supply chain industries that supply inputs to industry $j ; \alpha_{i}$ are I-O commodity weights from the BEA renormalized to sum to one; and $\operatorname{Reg}_{i, t}^{\text {direct }}$ are the direct federal restrictions for industry $i$ in year $t$ as reported by RegData.

\footnotetext{
${ }^{3}$ Staples et al. (2021) find significant heterogeneity in regulation restrictions in the beer industry across states, but they do they do not compare changes in industry-specific regulatory restrictions over time and across industries as we do here.

${ }^{4}$ Chambers et al. (2019) was first presented as a working paper by the Mercatus Center 2016.
} 
Next, we use State RegData and the input-output parameters to estimate the number of direct and indirect restrictions at the state level. The granularity of the industry regulation data provided by State RegData is limited to the NAICS three-digit level. We therefore use NAICS code 112 ("animal production and aquaculture"), which aggregates the four-digit industries of interest. State RegData is limited to regulations in 2020 only. Thus, all of the state-level regulations are limited to the aggregate animal production industries in 2020. The state indirect restrictions that apply to industry $j$ (i.e., animal protein production, processing, wholesale, or retail distribution) in state $h$ are

$$
\operatorname{Reg}_{j, h}^{\text {indirect }}=\sum_{i} \alpha_{i} \cdot \operatorname{Reg}_{i, h}^{\text {direct }}
$$

where $i$ is the index of industries that supply inputs to industry $j ; \alpha_{i}$ are the I-O commodity weights; and $\operatorname{Reg}_{i, h}^{\text {direct }}$ are the direct state restrictions for industry $i$ in state $h$ as reported by State RegData. For the sake of comparison, we also estimate the direct and indirect federal restrictions of all animal production and aquaculture (NAICS 112) as of 2019.

The BEA data are derived from the economic census (latest data are from 2012; see BEA, n.d.b) and are reported as "The Use Table (Supply-Use Framework), 2012," which records the dollar value of inputs from private and public entities and industries used as intermediate inputs to produce the output of an industry. ${ }^{5}$ After removing inputs from all non-private sector industries (i.e., federal, state, and local government enterprises) ${ }^{6}$ that provided less than $1.11 \%$ of all inputs, we normalized the remaining inputs to add to one (i.e. expressed as value-weighted inputs). ${ }^{7}$ Each industry's final inputs weights, $\alpha_{i}$, are presented in the Appendix accompanying this manuscript. ${ }^{8}$

Regulatory restrictions should be interpreted as a proxy rather than a full measure of regulatory cost. Counting restrictions provides no information on the intensity of a particular regulation, which could be restrictive or lax in practice. For example, our approach treats a regulation stating "the maximum line speed is 1,106 pigs per hour" as equivalent to a regulation stating "the maximum line speed is 2,212 pigs per hour," even though the former is more restrictive than the latter. ${ }^{9}$ Due to the paucity of research tying measures of regulations to actual regulatory costs, it is not possible to measure how closely regulatory restrictions correlate with regulatory burden. However, research on RegData finds that the number of restrictions declines in industries going through a period of deregulation, including air transportation and the Airline Deregulation Act of 1978, which shows that regulatory restrictions parallel actual regulatory trends and, by implication, regulatory costs (Al-Ubaydli and McLaughlin, 2017).

\section{Results}

Table 1 presents the number of direct restrictions at the federal level over time. Column one presents the regulatory year, columns two through seven correspond to the individual production

\footnotetext{
${ }^{5}$ The data can be obtained from https://www.bea.gov/industry/input-output-accounts-data\#tab-02 by clicking on Use Tables (Use of commodities by industry) for 2007, 2012 detailed (405) industries (https://apps.bea.gov/industry/xls/ioannual/Use_SUT_Framework_2007_2012_DET.xlsx). The dollar value of intermediate inputs from private and public entities and industries to produce the output of an industry are reflected in the columns of the table.

${ }^{6}$ The BEA defines government enterprises as "Government agencies that cover a substantial portion of their operating costs by selling goods and services to the public and that maintain their own separate accounts" (BEA, n.d.a).

${ }^{7}$ RegData does not estimate regulations that pertain to public sector entities, so the scope of input activity is restricted to non-public sector entities. Moreover, the only government sectors providing inputs to our five industries were the U.S. Postal Service and "other state and local government enterprises." In 2012, these public input sectors represented approximately $0 \%$ of the intermediate inputs for beef, poultry, and aquaculture production, $3.17 \%$ of the intermediate inputs for wholesale distribution, and $0.98 \%$ of the intermediate inputs for retail sales.

${ }^{8}$ The BEA does not directly report input weights for NAICS sector 1125, but instead provides I-O data for BEA industry code 112A (Animal production, except cattle and poultry and eggs), which comprise NAICS sectors 1122, 1124, 1125, and 1129.
}

${ }^{9} \mathrm{We}$ would like to acknowledge the contributions of a reviewer in raising this point. 
Table 1. Number of direct restrictions across animal protein value chains

\begin{tabular}{|cccccccccc}
\hline & $\begin{array}{c}\text { Cattle } \\
\text { ranching }\end{array}$ & $\begin{array}{c}\text { Hog and } \\
\text { pig }\end{array}$ & $\begin{array}{c}\text { Poultry and } \\
\text { egg }\end{array}$ & $\begin{array}{c}\text { Sheep and } \\
\text { goat }\end{array}$ & Aquaculture & $\begin{array}{c}\text { Other } \\
\text { animal }\end{array}$ & $\begin{array}{c}\text { Process- } \\
\text { ing }\end{array}$ & Wholesale & $\begin{array}{c}\text { Retail } \\
\text { sales }\end{array}$ \\
\hline NAICS & 1121 & 1122 & 1123 & 1124 & 1125 & 1129 & 311 X & 4244 & 4451 \\
\hline 1970 & 558 & 1,194 & 790 & 1,072 & 6,852 & 1,482 & 3,436 & 555 & 3,034 \\
\hline 1979 & 1,432 & 2,584 & 2,885 & 2,245 & 8,276 & 2,211 & 4,400 & 1,130 & 3,904 \\
\hline 1989 & 1,793 & 3,029 & 4,691 & 2,882 & 17,240 & 2,915 & 5,704 & 2,235 & 5,521 \\
\hline 1999 & 2,653 & 4,345 & 4,646 & 4,145 & 24,902 & 3,567 & 6,401 & 2,648 & 7,220 \\
\hline 2009 & 3,699 & 5,222 & 5,608 & 5,226 & 32,435 & 4,458 & 8,685 & 4,612 & 7,896 \\
\hline 2019 & 3,761 & 6,505 & 6,256 & 6,511 & 48,843 & 5,323 & 12,149 & 5,027 & 11,839 \\
\hline
\end{tabular}

Note: Yearly federal direct regulatory restrictions for each industry are presented in Table A2 of the Appendix accompanying this manuscript.

industries, and columns eight through ten present the number of downstream restrictions in the processing, wholesale, and retail sales industries, respectively. These estimates show that in 1970, cattle ranching was subject to 558 direct restrictions, 1,194 restrictions in hog and pig farming, 790 restrictions in poultry and eggs, 1,072 restrictions in sheep and goat farming, 6,852 restrictions in aquaculture, and 1,482 restrictions in other animal production. In 2019, there were 3,761 direct restrictions in cattle ranching, 6,505 restrictions in hog and pig farming, 6,256 restrictions in poultry and eggs, 6,511 restrictions in sheep and goat farming, 48,843 restrictions in aquaculture, and 5,323 restrictions in other animal industries. Thus, between 1970 and 2019, the estimated number of direct restrictions increased substantially in every production industry. If we pool industries based on three-digit NAICS codes to reduce double-counting regulations, then over this period regulatory restrictions in animal protein value chain increased $330 \%$.

The largest change in regulatory restrictions occurred in the aquaculture industry. We find an increase of more than 40,000 regulations between 1970 and 2019, more than a $600 \%$ increase. Additionally, aquaculture has the largest share of federal direct restrictions, and this share is growing. Figure 1 shows direct restrictions in each production industry as a share of the total number of regulations across all six industries. As the figure illustrates, since 1970, on average, more than $50 \%$ of direct restrictions associated with animal protein production can be linked to aquaculture, and since 2017 the share linked to aquaculture has exceeded $60 \%$.

There are also important relative changes among the other industries. Focusing on producers, the largest proportional increase-nearly 700\%—in direct regulations between 1970 and 2019 is associated with poultry. Downstream, however, direct regulations associated with wholesale distribution increased $800 \%$. Thus, when considering the entire value chain, federal direct regulations increased the most in the wholesale industry.

These trends change little when assessed in terms of the total number of regulatory restrictions, including direct and indirect regulations. Table 2 presents the total number of regulatory restrictions at the federal level for each industry, while Figure 2 plots the changes in restrictions over time for each of the six animal industries (four-digit NAICS code).

In general, total regulatory restrictions follow similar patterns of regulation and deregulation across industries over time. For instance, each industry sees significant increases-as much as a $25 \%$ increase year-over-year-in regulatory restrictions in 2017, coinciding with the final rulings on Mitigation Strategies to Protect Food Against Intentional Adulteration (21 CFR 11; 21 CFR 121) and Sanitary Transportation of Human and Animal Food (21 CFR 11), two components of the FDA Food Safety Modernization Act passed in $2011 .{ }^{10}$ As before, the largest overall increase

\footnotetext{
${ }^{10}$ The final ruling for Mitigation Strategies to Protect Food Against Intentional Adulteration (21 CFR 121) was published on May 27, 2016. The final ruling for Sanitary Transportation of Human and Animal Food (21 CFR 11) was published on April 6,
} 
Table 2. Total number of direct and indirect restrictions across animal protein value chains

\begin{tabular}{|cccccccccc}
\hline & $\begin{array}{c}\text { Cattle } \\
\text { ranching }\end{array}$ & $\begin{array}{c}\text { Hog and } \\
\text { pig }\end{array}$ & $\begin{array}{c}\text { Poultry and } \\
\text { egg }\end{array}$ & $\begin{array}{c}\text { Sheep and } \\
\text { goat }\end{array}$ & Aquaculture & $\begin{array}{c}\text { Other } \\
\text { animal }\end{array}$ & $\begin{array}{c}\text { Process- } \\
\text { ing }\end{array}$ & Wholesale & $\begin{array}{c}\text { Retail } \\
\text { sales }\end{array}$ \\
\hline NAICS & 1121 & 1122 & 1123 & 1124 & 1125 & 1129 & 311 X & 4244 & 4451 \\
\hline 1970 & 7,726 & 8,905 & 9,651 & 8,783 & 14,563 & 9,194 & 12,451 & 5,730 & 8,133 \\
\hline 1979 & 11,433 & 12,733 & 13,717 & 12,395 & 18,425 & 12,361 & 16,141 & 11,893 & 13,991 \\
\hline 1989 & 15,715 & 16,987 & 17,830 & 16,840 & 31,198 & 16,873 & 22,012 & 18,189 & 20,483 \\
\hline 1999 & 21,889 & 23,380 & 21,094 & 23,180 & 43,936 & 22,602 & 27,708 & 21,659 & 25,037 \\
\hline 2009 & 25,108 & 25,553 & 20,645 & 25,557 & 52,766 & 24,789 & 30,871 & 26,560 & 28,149 \\
\hline 2019 & 36,515 & 37,435 & 26,526 & 37,441 & 79,773 & 36,253 & 47,757 & 31,732 & 38,742 \\
\hline
\end{tabular}

Note: Yearly federal direct and indirect regulatory constraints for each industry are presented in Table A3 of the Appendix accompanying this manuscript.

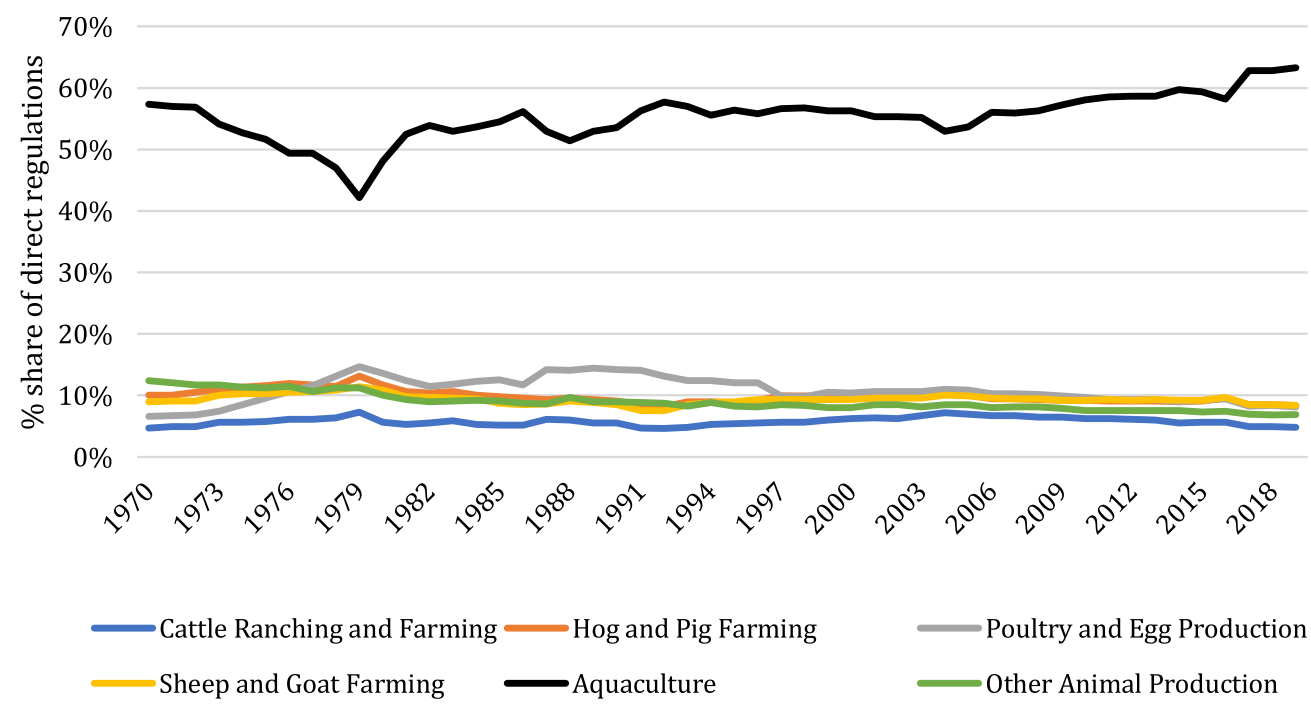

Figure 1. Estimated share of direct restrictions in federal law in different animal protein industries.

in restrictions across the 50 -year period is associated with aquaculture, although there is also a large relative change in the wholesale industry. However, the relative increase in restrictions associated with poultry is less pronounced than before, which indicates that indirect restrictions associated with poultry production have changed relatively little over the period of study. In contrast, the relative increase in restrictions associated with aquaculture is greater than before, which indicates that indirect restrictions associated with aquaculture production have increased more than restrictions in some other production industries (e.g. poultry).

2016. According to the Code of Federal Regulations (Annual Addition) (n.d.), the CFR annual addition codifies the 50 subject matter titles following a staggered schedule. Titles 1-16 are revised January 1; Titles 17-27 are revised as of April 1; Titles 28-41 are revised as of July 1; and Titles 42-50 are revised as of October 1. As Mitigation Strategies to Protect Food Against Intentional Adulteration was published in the CFR May 27, 2016 and Sanitary Transportation of Human and Animal Food was published April 6, 2016, the annual addition does not reflect the change to Title 21: Food and Drugs until April 1, 2017. Hence, these food policy initiatives are captured in the 2017 federal regulatory restrictions. 
Cattle ranching and farming (1121)

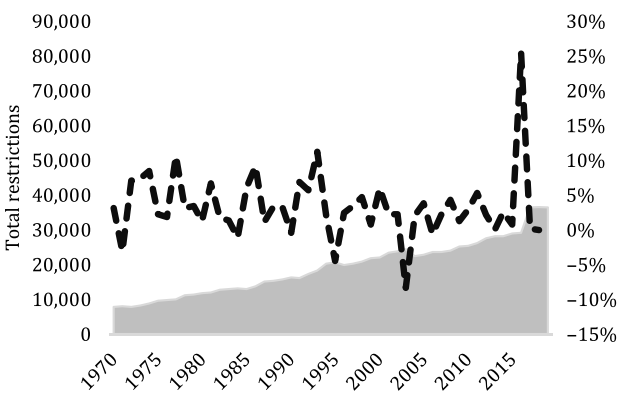

Poultry and egg production (1123)

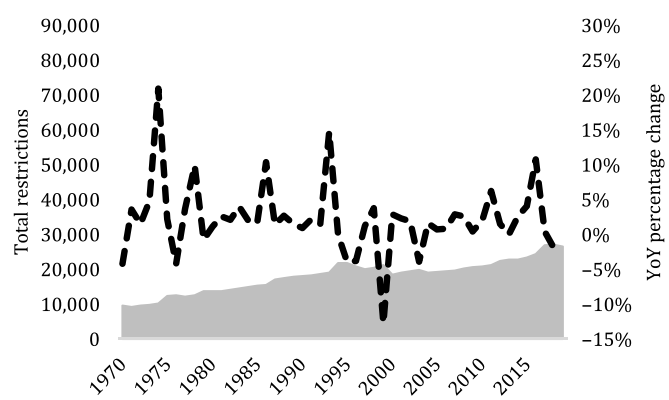

Aquaculture (1125)

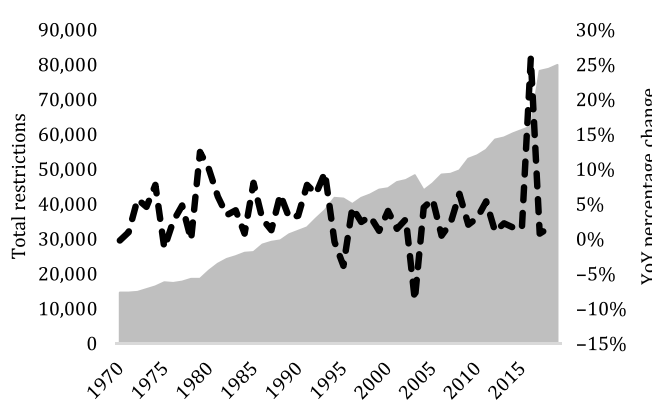

Hog and pig farming (1122)

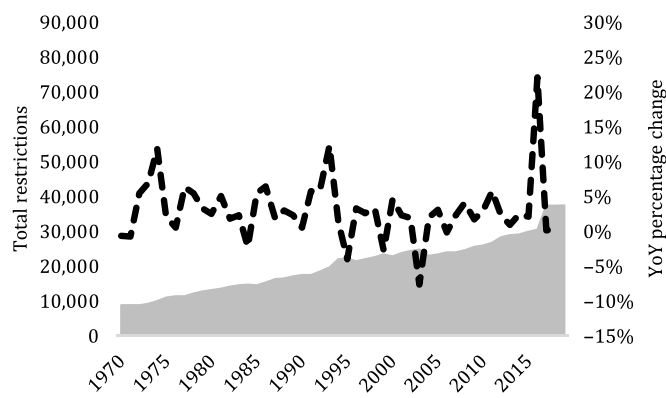

Sheep and goat farming (1124)

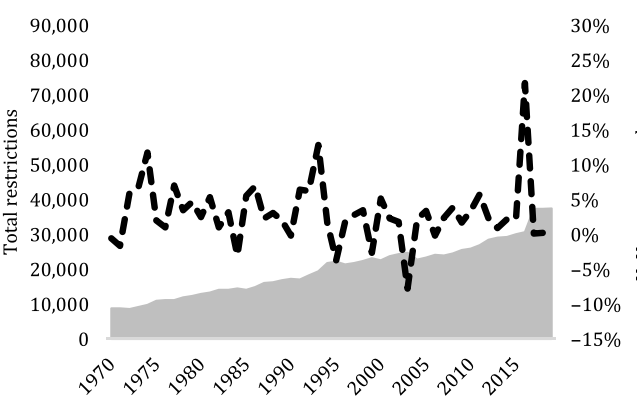

Other animal production (1129)

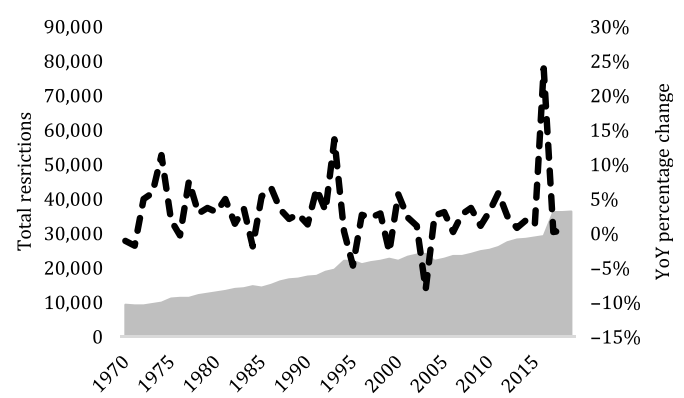

\section{Total federal regulatory restrictions}

\section{- - YoY percentage change}

Figure 2. Regulatory restrictions by animal industry (four-digit NAICS) over time and year-over-year (YoY) percentage change by industry.

Considering restrictive regulatory language at the state level, Table 3 presents the number of direct restrictions associated with animal production, animal processing, wholesale distribution, and retail sales. Recall, we cannot estimate the direct restrictions in each production industry (e.g. cattle ranching, pigs, and poultry) because State RegData only records regulatory restrictions at the three-digit NAICS level, while the production industries are at the fourdigit level. The estimates thus provide a sense of the variability in direct restrictions associated with animal production at the state level, which appears to be substantial. Table 3 shows that the number of direct restrictions associated with all animal production ranges from a low of 64 to a high of 12,324 - a relative difference of nearly $2,000 \%$. The average is 3,939 , with a standard deviation of 2,199 . There is modest correlation between the number of direct restrictions associated with animal production and the numbers associated with animal processing 
Table 3. Number of direct regulations by industry (3-digit NAICS code) at the state and federal level

\begin{tabular}{|c|c|c|c|c|c|}
\hline & All animals & Processing & Wholesale & Retail sales & Total \\
\hline NAICS & 112 & 311 & 424 & 445 & \\
\hline Alabama & 4,408 & 390 & 156 & 1,684 & 6,639 \\
\hline Arizona & 1,181 & 54 & 251 & 351 & 1,837 \\
\hline California & 8,052 & 2,416 & 555 & 5,753 & 16,775 \\
\hline Colorado & 6,822 & 529 & 306 & 1,399 & 9,056 \\
\hline Delaware & 3,777 & 399 & 799 & 4,249 & 9,225 \\
\hline District of Columbia & 1,114 & 501 & 893 & 1,654 & 4,162 \\
\hline Florida & 5,951 & 927 & 636 & 4,773 & 12,286 \\
\hline Georgia & 2,641 & 2,611 & 152 & 3,093 & 8,497 \\
\hline Idaho & 3,098 & 144 & 151 & 352 & 3,744 \\
\hline Illinois & 8,000 & 494 & 519 & 7,970 & 16,983 \\
\hline Indiana & 3,808 & 115 & 129 & 1,023 & 5,075 \\
\hline lowa & 4,516 & 611 & 194 & 2,697 & 8,019 \\
\hline Kansas & 1,044 & 242 & 204 & 1,092 & 2,582 \\
\hline Kentucky & 1,269 & 1,734 & 257 & 1,785 & 5,046 \\
\hline Louisiana & 8,033 & 628 & 124 & 5,003 & 13,787 \\
\hline Maine & 5,601 & 1,900 & 475 & 2,273 & 10,249 \\
\hline Maryland & 1,984 & 583 & 259 & 1,376 & 4,201 \\
\hline Massachusetts & 3,781 & 639 & 546 & 6,657 & 11,623 \\
\hline Michigan & 2,852 & 941 & 212 & 844 & 4,850 \\
\hline Minnesota & 3,668 & 1,842 & 238 & 1,826 & 7,574 \\
\hline Mississippi & 3,624 & 744 & 119 & 1,582 & 6,069 \\
\hline Missouri & 1,265 & 421 & 129 & 649 & 2,465 \\
\hline Montana & 3,472 & 528 & 123 & 411 & 4,534 \\
\hline Nebraska & 1,650 & 364 & 242 & 849 & 3,105 \\
\hline Nevada & 1,648 & 172 & 191 & 858 & 2,870 \\
\hline New Hampshire & 3,421 & 701 & 367 & 2,162 & 6,650 \\
\hline New York & 3,400 & 4,120 & 531 & 6,495 & 14,546 \\
\hline North Carolina & 4,395 & 272 & 350 & 2,286 & 7,303 \\
\hline North Dakota & 64 & 272 & 46 & 453 & 834 \\
\hline Ohio & 4,183 & 1,942 & 288 & 2,195 & 8,608 \\
\hline Oklahoma & 4,663 & 1,386 & 224 & 2,236 & 8,509 \\
\hline Oregon & 12,324 & 1,210 & 422 & 3,934 & 17,890 \\
\hline Pennsylvania & 1,161 & 2,173 & 239 & 2,077 & 5,651 \\
\hline Rhode Island & 9,035 & 524 & 489 & 1,078 & 11,126 \\
\hline South Carolina & 2,626 & 1,044 & 444 & 3,301 & 7,416 \\
\hline
\end{tabular}


Table 3. (Continued)

\begin{tabular}{|c|c|c|c|c|c|}
\hline & All animals & Processing & Wholesale & Retail sales & Total \\
\hline South Dakota & 383 & 457 & 27 & 100 & 967 \\
\hline Tennessee & 1,310 & 813 & 221 & 2,844 & 5,188 \\
\hline Texas & 4,031 & 963 & 2,598 & 4,823 & 12,415 \\
\hline Utah & 3,066 & 392 & 289 & 1,103 & 4,851 \\
\hline Virginia & 3,994 & 856 & 208 & 4,865 & 9,924 \\
\hline Washington & 10,717 & 1,528 & 753 & 4,941 & 17,938 \\
\hline West Virginia & 2,968 & 868 & 195 & 1,680 & 5,709 \\
\hline Wisconsin & 6,162 & 1,757 & 292 & 2,648 & 10,860 \\
\hline Wyoming & 2,135 & 241 & 189 & 1,112 & 3,677 \\
\hline U.S. federal (2019) & 44,757 & 22,903 & 5,027 & 11,839 & 84,526 \\
\hline
\end{tabular}

( $\rho=0.186)$, wholesale distribution $(\rho=0.211)$, and retail sales $(\rho=0.525)$, which implies that states with a relatively large number of direct regulations in one industry tend to have relatively more regulations overall. This pattern of heterogeneity suggests important differences in how states have written their laws. Generally, these differences are less pronounced between neighboring states and correlate with population and the level of economic activity. For example, South and North Dakota have the lowest numbers of direct regulations associated with animal production, compared to Oregon, Washington state, and California with the highest numbers.

Table 4 presents the total (direct and indirect) restrictions by industry (3-digit NAICS code), and Figure 3 presents these results graphically. The range of total restrictions associated with animal production is between 715 (North Dakota) and 18,010 (Oregon); between 885 (North Dakota) and 21,570 (Oregon) for processing; between 246 (South Dakota) and 8,221 (Texas) for wholesale; and between 325 (South Dakota) and 12,234 (Illinois) for retail. The estimates reveal that states with a lower number of direct regulations tend to have fewer total regulations. Indeed, if we ranked states by regulatory restrictions associated with animal production, the rankings would change little if we used direct rather than total restrictions, as there is a high degree of correlation between direct and indirect restrictions $(\rho=0.983)$. Setting aside animal processing, for which animal production is a key input, the total number of regulatory restrictions associated with animal production is greater than that of wholesale distribution and retail sales. Further, $73 \%$ of states in our data set (32 of 44 jurisdictions) have more restrictions associated with animal production than wholesale and retail sales. However, there are more total regulatory restrictions associated with animal processing than any of the other three-digit industries, although this is driven mainly by indirect restrictions.

Our estimates indicate a larger number of restrictions at the federal level than at the state level. The last row of Tables 3 and 4 include the estimates of direct and total restrictions at the federal level for each of the three three-digit NAICS industries, respectively. In every industry category, the number of federal restrictions exceeds the number of restrictions in any state, including direct and total restrictions.

\section{Discussion}

The result that direct restrictions associated with the animal protein value chain have increased by more than a factor of three needs to be taken in context. When computed on an annualized basis, 
Table 4. Number of total direct and indirect restrictions by industry (3-digit NAICS code) at the state and federal level

\begin{tabular}{|c|c|c|c|c|c|}
\hline & All animals & Processing & Wholesale & Retail sales & Total \\
\hline NAICS & 112 & 311 & 424 & 445 & \\
\hline Alabama & 6,719 & 7,594 & 1,532 & 2,791 & 18,636 \\
\hline Arizona & 1,996 & 2,192 & 994 & 1,005 & 6,188 \\
\hline California & 13,269 & 19,486 & 6,921 & 11,992 & 51,668 \\
\hline Colorado & 10,469 & 12,220 & 3,953 & 4,366 & 31,008 \\
\hline Delaware & 6,253 & 7,118 & 2,920 & 6,164 & 22,455 \\
\hline District of Columbia & 1,940 & 2,880 & 2,391 & 2,855 & 10,066 \\
\hline Florida & 9,127 & 10,847 & 2,608 & 6,561 & 29,142 \\
\hline Georgia & 5,172 & 8,750 & 3,054 & 5,455 & 22,431 \\
\hline Idaho & 4,471 & 5,076 & 775 & 932 & 11,255 \\
\hline Illinois & 12,607 & 14,416 & 4,978 & 12,234 & 44,234 \\
\hline Indiana & 5,699 & 6,816 & 1,486 & 2,218 & 16,218 \\
\hline lowa & 6,964 & 8,429 & 2,302 & 4,625 & 22,320 \\
\hline Kansas & 1,783 & 2,400 & 1,170 & 1,978 & 7,331 \\
\hline Kentucky & 2,666 & 5,397 & 1,401 & 2,912 & 12,376 \\
\hline Louisiana & 12,104 & 13,700 & 2,463 & 7,061 & 35,327 \\
\hline Maine & 8,771 & 12,171 & 3,171 & 4,586 & 28,698 \\
\hline Maryland & 3,294 & 4,443 & 1,853 & 2,739 & 12,329 \\
\hline Massachusetts & 6,066 & 8,124 & 3,886 & 9,655 & 27,731 \\
\hline Michigan & 4,749 & 6,361 & 1,531 & 2,280 & 14,921 \\
\hline Minnesota & 6,347 & 9,134 & 2,114 & 3,748 & 21,344 \\
\hline Mississippi & 5,852 & 7,922 & 3,405 & 4,291 & 21,470 \\
\hline Missouri & 2,214 & 3,221 & 1,692 & 2,052 & 9,179 \\
\hline Montana & 5,388 & 6,391 & 1,181 & 1,541 & 14,501 \\
\hline Nebraska & 2,634 & 3,575 & 1,742 & 2,164 & 10,115 \\
\hline Nevada & 2,511 & 3,100 & 988 & 1,705 & 8,303 \\
\hline New Hampshire & 5,430 & 7,395 & 4,020 & 5,113 & 21,958 \\
\hline New York & 6,990 & 13,570 & 5,218 & 10,986 & 36,764 \\
\hline North Carolina & 6,711 & 7,570 & 1,835 & 3,718 & 19,834 \\
\hline North Dakota & 715 & 885 & 793 & 1,091 & 3,484 \\
\hline Ohio & 6,909 & 10,261 & 2,657 & 4,357 & 24,184 \\
\hline Oklahoma & 7,435 & 10,071 & 2,897 & 4,831 & 25,234 \\
\hline Oregon & 18,010 & 21,570 & 4,317 & 7,477 & 51,374 \\
\hline Pennsylvania & 2,779 & 5,966 & 1,742 & 3,520 & 14,006 \\
\hline Rhode Island & 12,895 & 14,857 & 2,261 & 2,669 & 32,683 \\
\hline South Carolina & 4,653 & 6,474 & 2,062 & 4,750 & 17,938 \\
\hline
\end{tabular}


Table 4. (Continued)

\begin{tabular}{|c|c|c|c|c|c|}
\hline & All animals & Processing & Wholesale & Retail sales & Total \\
\hline South Dakota & 779 & 1,407 & 246 & 325 & 2,757 \\
\hline Tennessee & 2,944 & 4,122 & 2,087 & 4,441 & 13,594 \\
\hline Texas & 7,003 & 9,936 & 8,221 & 9,935 & 35,096 \\
\hline Utah & 4,939 & 5,856 & 1,957 & 2,538 & 15,290 \\
\hline Virginia & 7,096 & 8,670 & 3,614 & 7,975 & 27,355 \\
\hline Washington & 16,184 & 19,720 & 4,677 & 8,721 & 49,302 \\
\hline West Virginia & 4,843 & 6,647 & 1,806 & 3,365 & 16,661 \\
\hline Wisconsin & 10,234 & 13,760 & 2,696 & 4,946 & 31,636 \\
\hline Wyoming & 3,281 & 4,284 & 1,635 & 2,371 & 11,570 \\
\hline U.S. federal (2019) & 73,122 & 108,045 & 31,732 & 38,742 & 251,640 \\
\hline
\end{tabular}

this result implies a 3\% per year increase in direct restrictions across the value chain. This exceeds the increase in overall regulatory restrictions in the CFR since the 1970s, which have grown about $2 \%$ per year, although it is lower than the increase in EPA-related regulations, which have grown $5 \%$ per year (McLaughlin and Sherouse, 2019). Nevertheless, there can be substantial variation in regulation growth between individual industries, and comparison with prior research suggests that regulation in the animal protein value chain as a whole is intensifying faster than in many other industries (Al-Ubaydli and McLaughlin, 2017; Malone and Chambers, 2017). Moreover, by breaking down regulatory restrictions by industry sector, our results show that restrictions are growing fastest in the wholesale distribution, poultry, and aquaculture industries, while restrictions associated with animal processing and retail sales growing at rates closer to the overall average.

The results reveal differences in the numbers of regulatory restrictions at the federal level associated with animal production industries, numbers that appear relatively modest in the context of one exceptionally striking case. The number of federal restrictions has risen steadily since 1970, across all animal production industries, which likely reflects a general increase in the body of federal law with ties to agriculture and food production. Between cattle ranching, pig farming, poultry and egg production, sheep and goat farming, and other animal industries, there are an estimated 3,701-6,511 direct restrictions, depending on the industry, as of 2019. These differences may be important, but they appear modest when compared to an estimated 48,843 direct regulations associated with aquaculture in 2019. Indeed, we find that for nearly the last half a century, the number of direct and total regulations associated with aquaculture has been approximately double the number of regulations in the other five: cattle ranching, pig farming, poultry and egg production, sheep and goat farming, and other animal industries.

These estimates lend credibility to calls to reduce regulatory costs in aquaculture (Engle et al., 2019). In federal law, more regulatory restrictions are associated with aquaculture than with other industries, including downstream industries associated with consumer safety (i.e., retail sales) and animal production industries that, like aquaculture, have raised concerns about environmental impact (e.g. poultry and egg production). The disparity in these estimates is consistent with claims by some aquaculture industry stakeholders and public officials that overlapping federal agency responsibilities make aquaculture regulations difficult to navigate. While we lack the data to investigate whether this is also true for aquaculture at the state level, we do, however, find evidence that state law has more regulatory language associated with animal production as a whole industry than with wholesale distribution and retail sales, which suggests that regulations at the state level could still disproportionately affect animal producers (including aquaculture) more than is 
Panel A. Animal Production (112)

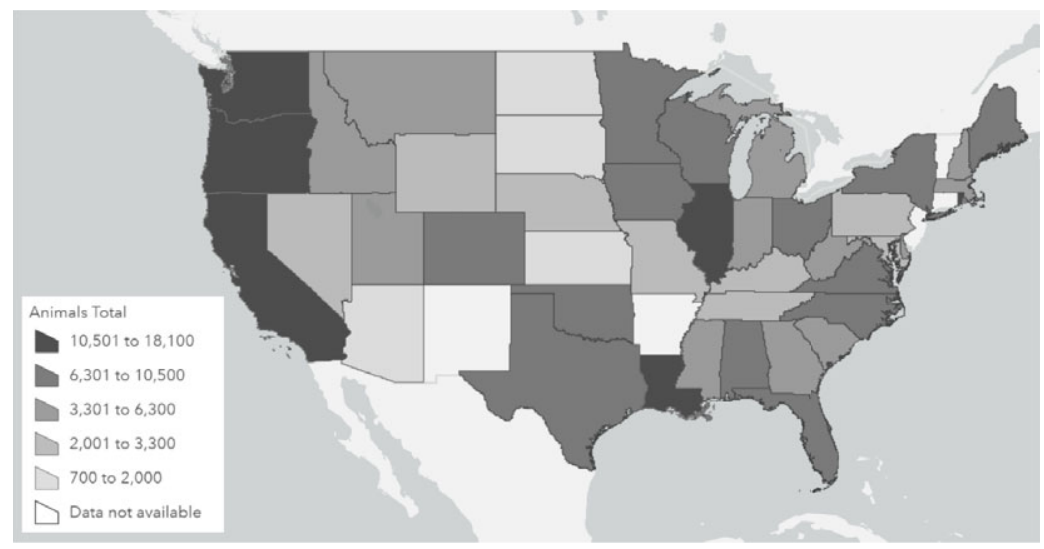

Panel B. Wholesale (424)

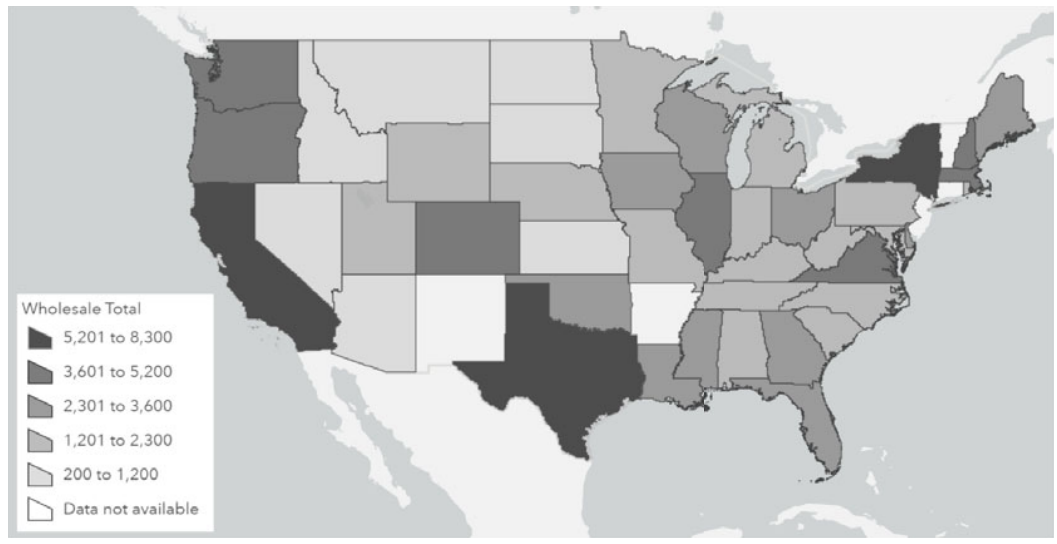

Panel C. Retail (445)

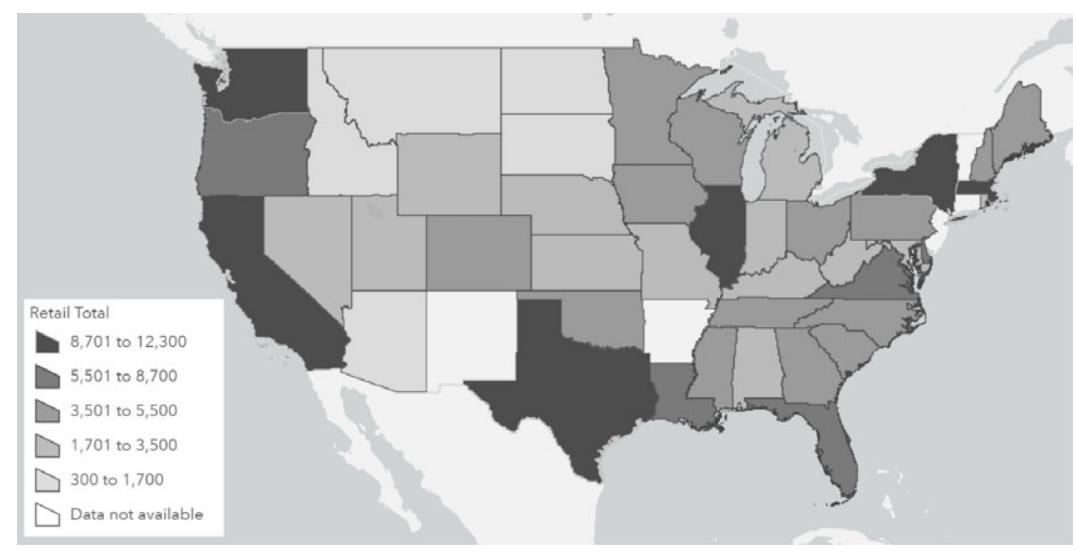

Figure 3. Total direct and indirect regulatory restrictions by industry (3-digit NAICS code) by state. 
generally the case with other industries. However, the relative differences between industries at the state level are smaller than the relative difference between aquaculture and other industries at the federal level.

One explanation for additional regulation of aquaculture is the industry's reliance on large amounts of water and varied sources of pollution risk. In the United States, water pollution regularly tops the list of public concerns (Sheth, 2019), putting continuous pressure on federal policy makers to develop and revise laws to limit and clean up sources of wastewater. Aquaculture can affect water quality through discharges of fish manure, feed waste, antibiotics, and outbreaks of fish disease. Fish can be raised in near-shore, pond, flow-through, and tank-based production systems, each of which can come with a unique set of water quality concerns and controls, and thus contribute to a larger and more complex of set of regulations than those experienced by other livestock operations. Indeed, research finds water quality regulations create among the most salient regulatory costs in the aquaculture industry (Engle et al., 2019). A related explanation for additional regulation of aquaculture is that in addition to the FDA and the USDA, which monitors compliance with animal production laws, aquaculture with point-source discharge is subject to monitoring by the EPA and marine aquaculture is subject to monitoring by the NOAA. Put simply, the greater number of restrictions associated with aquaculture could be due to a mix of environmental and food law.

Our results also indicate that a large number of regulatory restrictions at the state level can potentially affect production and distribution of animal products. Including direct and indirect regulations, there are, on average, several thousand state restrictions associated with animal production, as well as with animal processing, wholesale distribution, and retail sales. However, these results do not imply that states with more restrictions are worse off in terms of production. In fact, comparing cash receipts in various animal production sectors with direct restrictions at the state level, we find correlations close to zero. ${ }^{11}$ This insight may have important implications for our estimates of federal restrictions, because the differences in restrictions between states are generally larger than the estimates of federal restrictions between industries. The states with the most restrictions have many thousands more restrictions than the states with the fewest. Explaining these differences goes beyond the scope of this article, but the number of regulatory restrictions clearly correlates with the amount of economic activity in a state. ${ }^{12}$ Thus, we think much of the heterogeneity in regulatory restrictions is tied to legislatures' responses to increasingly complex state economies.

Of course, our estimates of state-level restrictions up and down the value chain should be interpreted carefully. Thousands of regulatory restrictions affect production of beef, pigs, chickens, and other animals, and the number of these restrictions vary greatly by industry and state. Among the sectors we examined, at the federal level, aquaculture appears to be the most regulated. However, as noted above, regulatory restriction counts do not definitively indicate that certain industries or states may be "overregulated" or insufficiently regulated. To highlight this point by way of example, we compare estimates of total regulations associated with animal production in Michigan and Missouri: there are more than twice as many regulations in Michigan $(2,852)$ than in Missouri $(1,265)$ as well as more regulations associated with wholesale distribution and retail sales in Michigan; yet compared with Michigan, Missouri is not considered to have a better regulatory environment. In fact, at least one ranking places Michigan at the top in terms of regulatory relief (Ruger and Sorens, 2009). Thus, the large number of federal restrictions associated with

\footnotetext{
${ }^{11}$ The correlation between the number of direct restrictions in the animal production and 2019 cash receipts in meat, cattle and poultry production is $-0.096,-0.116$, and -0.034 , respectively. In contrast, the correlation between direct restrictions and 2019 catch receipts in all agricultural commodities is 0.215 . Results available upon request.

${ }^{12}$ For example, California, Texas and New York have the largest gross state products, and these are generally in the group of states with the most restrictive regulatory language, regardless of industry. Furthermore, the correlation between gross state product and the number of total restrictions in the animal production, animal processing, wholesale distribution, and retail sales industries is $0.334,0.470,0.719$ and 0.700 , respectively.
} 
aquaculture should be interpreted with caution, as regulatory costs may not be restricting growth in industry as much as the estimates appear to suggest.

It should also be noted that regulations are often intended to solve problems and can be good for producers and economic activity. Legal restrictions can be valuable because they protect consumers, protect the environment, define property rights, track economic activity, etc. States and the federal government can thus use restrictions to promote as much as to restrain business, and more restrictions need not imply that a sector or industry is overregulated.

\section{Conclusion}

Food regulations protect the consumer, mitigate environmental concerns, and promote animal welfare, but they can also hinder innovation, limit entrepreneurship, and generate higher consumer prices (Carter et al., 2021; Malone and Lusk, 2016a, 2016b; McCluskey, Wesseler, and Winfree, 2018; Mullally and Lusk, 2018). Despite an extensive literature on the unintended consequences of regulations, few studies have investigated regulatory restrictions across supply chains. We use Mercatus Center's RegData and State RegData databases to explore regulatory restrictions across various protein supply chains, including beef, pig, poultry, sheep, goat, and seafood. Results suggest that, between 1970 and 2019, the total number of regulatory restrictions at the federal level increased significantly for each protein source, with aquaculture appearing to be the most heavily affected. Further, our results highlight the extreme heterogeneity in the way states regulate animal protein supply chains.

Food policy and food system resiliency have received heightened attention due to the COVID19 pandemic (Rivera-Ferre et al., 2021; Thilmany et al., 2021; Weersink et al., 2021), concerns over climate change (Hunter and Röös, 2016; Jalil, Tasoff, and Bustamante, 2020), enhanced food insecurity (Gundersen, Kreider, and Pepper, 2017), and consumer sentiment for animal welfare (Clark et al., 2017). Our results demonstrate a patchwork approach to food regulation, which risks creating overlapping, cumbersome guidelines for food manufacturers and industry groups. Additionally, given the interconnectivity of modern food supply chains, the patchwork system can create additional hurdles for interstate commerce, particularly given the significant heterogeneity in food regulations across state boundaries. At a minimum, the cost of a regulation is a compliance cost - the cost of time to read, understand, and abide by the regulation, which can prevent market entry and hinder industry innovation-particularly in emerging, niche markets.

We identify two limitations to our methodology. First, given the lack of granularity of the data, we were unable to partition the state regulatory restrictions by animal protein source. While federal regulatory restrictions use the four-digit NAICS codes (e.g., NAICS 1121: Cattle ranching and farming), State RegData codifies on the three-digit NAICS level (NAICS 112: Animal production). While this limitation prevents a more thorough analysis of the regulatory restrictions at the state level, our analysis provides initial insights into the animal production regulatory patterns across the United States.

Secondly, RegData accounts only for the total number of regulatory restrictions as a proxy for regulatory burden and does not consider any qualitative components of the restrictions. In other words, our approach cannot measure the restrictiveness of each regulatory statement. We acknowledge that there is validity to this concern. Of course, incorporating a method to quality-weight regulatory statements based upon their restrictiveness would offer tremendous insight and enable us to better understand regulatory restrictions. However, no such qualityweighting method exists. Further, RegData offers a substantial improvement over the next-best alternatives (Al-Ubaydli and McLaughlin, 2017), which includes simply counting the total number of pages published in the Federal Register or using the size of digitized versions of statutes to measure regulations (Coffey, McLaughlin, and Tollison, 2012; Dawson and Seater, 2013; Mulligan and Shleifer, 2005). 
Despite these shortcomings, this article speaks to the changes in regulatory restrictions across protein supply chains over time as well as the heterogeneity among states. While unable to speak to the intensity or cost of each regulatory restriction, we capture the fact that protein supply chains have become subject to tens of thousands of regulatory restrictions. Future research is needed to examine the economic consequences of these regulatory restrictions. By examining changes in industry production practices, market prices, and consumer preferences after significant policy changes, future work could better answer the question of regulatory impacts.

Acknowledgments. The authors would like to thank the reviewers for their helpful comments and suggestions, as their feedback significantly improved the manuscript.

Author contributions. Conceptualization, T.M.; Methodology, D.C., R.T.M. and T.M.; Formal Analysis, D.C.;Data Curation, D.C.; Writing-Original Draft, A.J.S., D.C., R.T.M. and T.M.,Writing-Review and Editing, A.J.S., R.T.M. and T.M.; Supervision, R.T.M. andT.M.; Funding Acquisition, R.T.M. and T.M.

Competing interests. The authors declare no competing interests.

Data Availability Statement. Data will be made available upon request.

Financial support. This work was supported by the National Oceanic and Atmospheric Administration, Award ID 01325300001 .

\section{References}

Al-Ubaydli, O., and P.A. McLaughlin. "RegData: A numerical database on industry-specific regulations for all United States industries and federal regulations, 1997-2012.” Regulation \& Governance 11,1(2017):109-23. https://doi.org/10.1111/rego. 12107

BEA (n.d.a). “Government enterprises.” Internet site: https://www.bea.gov/index.php/help/glossary/government-enterprises

BEA (n.d.b). "Input-Output accounts data." Internet site: https://www.bea.gov/industry/input-output-accounts-data

Bovay, J., and J.M. Alston. "GMO food labels in the United States: Economic implications of the new law." Food Policy 78(2018):14-25. https://doi.org/10.1016/j.foodpol.2018.02.013

Carter, C.A., K.A. Schaefer, and D. Scheitrum. "Piecemeal farm regulation and the US Commerce Clause." American Journal of Agricultural Economics 103,3(2021):1141-63. https://doi.org/10.1111/ajae.12104

Chambers, D., C.A. Collins, and A. Krause. "How do federal regulations affect consumer prices? An analysis of the regressive effects of regulation.” Public Choice 180,1(2019):57-90. https://doi.org/10.1007/s11127-017-0479-z

Clark, B., G.B. Stewart, L.A. Panzone, I. Kyriazakis, and L.J. Frewer. "Citizens, consumers and farm animal welfare: A meta-analysis of willingness-to-pay studies.” Food Policy 68(2017):112-27. https://doi.org/10.1016/j.foodpol.2017.01.006

Code of Federal Regulations (Annual Addition) (n.d.). “About the Code of Federal Regulations.” Internet site: https://www. govinfo.gov/help/cfr\#about

Coffey, B., P.A. McLaughlin, and R.D. Tollison. “Regulators and redskins.” Public Choice 153,1(2012):191-204. https://doi. org/10.1007/s11127-011-9781-3

Dawson, J.W., and J.J. Seater. "Federal regulation and aggregate economic growth." Journal of Economic Growth 18(2013):137-77. https://doi.org/10.1007/s10887-013-9088-y

Djankov, S., R. La Porta, F. Lopez-de-Silanes, and A. Shleifer. “The regulation of entry.” The Quarterly Journal of Economics 117,1(2002):1-37. https://doi.org/10.1162/003355302753399436

Engle, C.R., J. van Senten, and G. Fornshell. "Regulatory costs on US salmonid farms." Journal of the World Aquaculture Society 50,3(2019):522-49. https://doi.org/10.1111/jwas.12604

Escalante, C.L., T. Luo, and C.E. Taylor. "The availability of H-2A guest farm workers during the COVID-19 pandemic." Choices 35,3(2020):1-8. https://doi.org/10.22004/ag.econ.305279

FAO. "National aquaculture sector overview. United States of America." 2021a. Internet site: http://www.fao.org/fishery/ countrysector/naso_usa/en

FAO. "National aquaculture legislation overview. United States of America." 2021b. Internet site: http://www.fao.org/fishery/ legalframework/nalo_usa/en

FDA. "Retail food protection." 2020. Internet site: https://www.fda.gov/food/guidance-regulation-food-and-dietarysupplements/retail-food-protection

Fortin, N. "Introduction to food regulation." Food Regulation: Law, Science, Policy, and Practice. N. Fortin, ed. Hoboken, NJ: John Wiley \& Sons, 2017, pp. 3-20.

GAO. "Regulatory burden: Measurement challenges and concerns raised by selected companies." 1996. Internet site: https:// www.gao.gov/products/ggd-97-2 
Gundersen, C., B. Kreider, and J.V. Pepper. "Partial identification methods for evaluating food assistance programs: A case study of the causal impact of SNAP on food insecurity." American Journal of Agricultural Economics 99,4(2017):875-93. https://doi.org/10.1093/ajae/aax026

Hunter, E., and E. Röös. "Fear of climate change consequences and predictors of intentions to alter meat consumption." Food Policy 62(2016):151-60. https://doi.org/10.1016/j.foodpol.2016.06.004

Hyink, J., and R. Melstrom, (2021). "Summary of aquaculture in the United States. Loyola University Chicago eCommons." Internet site: https://ecommons.luc.edu/ies_facpubs/39/

Jalil, A.J., J. Tasoff, and A.V. Bustamante. "Eating to save the planet: Evidence from a randomized controlled trial using individual-level food purchase data." Food Policy 95(2020):101950. https://doi.org/10.1016/j.foodpol.2020.101950

Kolodinsky, J., and J.L. Lusk. "Mandatory labels can improve attitudes toward genetically engineered food." Science Advances 4,6(2018):eaaq1413. https://doi.org/10.1126/sciadv.aaq1413

Lusk, J.L., G.T. Tonsor and L.L. Schulz. "Beef and pork marketing margins and price spreads during COVID-19.” Applied Economic Perspectives and Policy 43,1(2021):4-23. https://doi.org/10.1002/aepp.13101

MacDonald, J. (2008). “The economic organization of U.S. broiler production." Economic Information Bulletin No. 38. Internet site: https://www.ers.usda.gov/webdocs/publications/44254/12067_eib38_1_.pdf?v=0

Mallory, M.L. "Impact of COVID-19 on medium-term export prospects for soybeans, corn, beef, pork, and poultry." Applied Economic Perspectives and Policy 43,1(2021):292-303. https://doi.org/10.1002/aepp.13113

Malone, T., and D. Chambers. "Quantifying federal regulatory burdens in the beer value chain." Agribusiness 33,3(2017):466-71. https://doi.org/10.1002/agr.21507

Malone, T., and J.L. Lusk. "Brewing up entrepreneurship: Government intervention in beer." Journal of Entrepreneurship and Public Policy 5,3(2016a):325-42. https://doi.org/10.1108/JEPP-02-2016-0004

Malone, T., and J.L. Lusk. "Putting the chicken before the egg price: An 'ex post' analysis of California's battery cage ban." Journal of Agricultural and Resource Economics 41,3(2016b):518-32. https://www.jstor.org/stable/44131353

Malone, T., K.A. Schaefer, and J.L. Lusk. "Unscrambling egg supply chains amid COVID-19." Food Policy 101(2021):102046. https://doi.org/10.1016/j.foodpol.2021.102046

Malone, T., and M. Stack. "What do beer laws mean for economic growth?” Choices 32,3(2017):1-7. https://www.jstor.org/ stable/90015011

Martinez, C.C., J.G. Maples, and J. Benavidez. "Beef cattle markets and COVID-19." Applied Economic Perspectives and Policy 43,1(2021):304-14. https://doi.org/10.1002/aepp.13080

McCluskey, J.J., J. Wesseler, and J.A. Winfree. "The economics and politics of GM food labeling: An introduction to the special issue.” Food Policy 78(2018):1-5. https://doi.org/10.1016/j.foodpol.2018.02.012

McKendree, M.G., C.C. Croney, and N.J.O. Widmar. "Effects of demographic factors and information sources on United States consumer perceptions of animal welfare." Journal of Animal Science 92,7(2014):3161-73. https://doi.org/10.2527/jas. 2014-6874

McLaughlin, P.A., and O. Sherouse. "RegData 2.2: a panel dataset on US federal regulations.” Public Choice 180,1(2019):4355. https://doi.org/10.1007/s11127-018-0600-y

Mitigation strategies to protect food against intentional adulteration: 21 CFR 11; 21 CFR 121. 2016. Internet site: https://www. federalregister.gov/documents/2016/05/27/2016-12373/mitigation-strategies-to-protect-food-against-intentional-adulteration

Mojduszka, E.M., and J.A. Caswell. "A test of nutritional quality signaling in food markets prior to implementation of mandatory labeling.” American Journal of Agricultural Economics 82,2(2000):298-309. https://doi.org/10.1111/0002-9092. 00026

Mullally, C., and J.L. Lusk. "The impact of farm animal housing restrictions on egg prices, consumer welfare, and production in California." American Journal of Agricultural Economics 100,3(2018):649-69. https://doi.org/10.1093/ajae/aax049

Mulligan, C.B., and A. Shleifer. "The extent of the market and the supply of regulation." The Quarterly Journal of Economics 120,4(2005):1445-73. https://doi.org/10.1162/003355305775097579

Ortega, D.L., and C.A. Wolf. "Demand for farm animal welfare and producer implications: Results from a field experiment in Michigan.” Food Policy 74(2018):74-81. https://doi.org/10.1016/j.foodpol.2017.11.006

Pasiakos, S.M., S. Agarwal, H.R. Lieberman, and V.L. Fulgoni. "Sources and amounts of animal, dairy, and plant protein intake of US adults, 2007-2010.” Nutrients 7,8(2015):7058-69. https://doi.org/10.3390/nu7085322

Rivera-Ferre, M.G., F. López-i-Gelats, F. Ravera, E. Oteros-Rozas, M. di Masso, R. Binimelis, and H. El Bilali. "The relation of food systems with the COVID19 pandemic: Causes and consequences." Agricultural Systems (2021):103134. https:// doi.org/10.1016/j.agsy.2021.103134

Ruger, W.M. and J. Sorens. (2009). "Freedom in the 50 States - An index of personal and economic freedom." Mercatus Center. Internet site: https://www.mercatus.org/publications/regulation/freedom-50-states-index-personal-and-economicfreedom

Sanitary transportation of human and animal food: 21 CFR 1; 21 CFR 11. 2016. Internet site: https://www.federalregister. gov/documents/2016/04/06/2016-07330/sanitary-transportation-of-human-and-animal-food

Shahbandeh, M. "Leading protein sources among consumers in the United States as of April 2017." Statistica, 2018. Internet site: https:/www.statista.com/statistics/251602/us-consumers-sources-of-protein/ 
Shamshak, G.L., J.L. Anderson, F. Asche, T. Garlock, and D.C. Love. "US seafood consumption." Journal of the World Aquaculture Society 50,4(2019):715-27. https://doi.org/10.1111/jwas.12619

Sheth, S. “America's Top Fears 2019.” Chapman University Survey of American Fears, 2019. Internet site: https://www. chapman.edu/wilkinson/research-centers/babbie-center/_files/americas-top-fears-2019.pdf

Staples, A.J., D. Chambers, and T. Malone. (2021). "How many regulations does it take to get a beer? The geography of beer regulations." Regulation \& Governance. https://doi.org/10.1111/rego.12403

Stigler, G.J. “The theory of economic regulation.” The Bell Journal of Economics and Management Science 2,1(1971):3-21. https://doi.org/10.2307/3003160

Strauss, D.M. "An analysis of the FDA Food Safety Modernization Act: Protection for consumers and boon for business." Food and Drug Law Journal 66,3(2011):353-76. http://www.jstor.org/stable/26661214

Sumner, D.A. "Economics of US state and local regulation of farm practices, with emphasis on restrictions of interstate trade." Annual Review of Resource Economics 9(2017):13-31. https://doi.org/10.1146/annurev-resource-100516-053646

Thatte, D. "The Food Safety Modernization Act in a Nutshell." National Institute of Standards and Technology, October 17, 2019. Internet site: https://www.nist.gov/blogs/manufacturing-innovation-blog/food-safety-modernization-act-nutshell

Thilmany, D., E. Canales, S.A. Low, and K. Boys. "Local food supply chain dynamics and resilience during COVID-19." Applied Economic Perspectives and Policy 43,1(2021):86-104. https://doi.org/10.1002/aepp.13121

Thilmany, D., and T. Malone. "COVID-19 Gives Chance to Take a Fresh Look at How Innovative Food Systems are Regulated." Food Logistics, May 11, 2020. Internet site: https://www.foodlogistics.com/sustainability/article/21131349/ covid19-gives-chance-to-take-a-fresh-look-at-how-innovative-local-food-systems-are-regulated

USDA-ERS. "Food availability (per capita) data system: Red meat, poultry, and fish." Economic Research Service, 2019. Internet site: https://www.ers.usda.gov/data-products/food-availability-per-capita-data-system/

USDA-ERS. "Since 1970, increasing cattle weights have fueled growth of U.S. beef production as cattle used have decreased." 2021. Internet site: https://www.ers.usda.gov/data-products/chart-gallery/gallery/chart-detail/?chartId=93225

USDA-FSIS. "Food safety acts." 2016. Internet site: https://www.fsis.usda.gov/policy/food-safety-acts

Weersink, A., M. von Massow, N. Bannon, J. Ifft, J. Maples, K. McEwan, ... K. Wood. "COVID-19 and the agri-food system in the United States and Canada.” Agricultural Systems 188(2021):103039. https://doi.org/10.1016/j.agsy.2020. 103039

Zago, A.M., and D. Pick. "Labeling policies in food markets: Private incentives, public intervention, and welfare effects." Journal of Agricultural and Resource Economics 29,1(2004):150-65. https://www.jstor.org/stable/40987237 


\section{Appendix}

Table A1. I-O supply chain industry weights

\begin{tabular}{|c|c|c|c|c|c|c|c|c|c|}
\hline \multirow[b]{2}{*}{ NAICS } & \multirow[b]{2}{*}{$\begin{array}{l}\text { Industry } \\
\text { description }\end{array}$} & \multicolumn{8}{|c|}{ Input weights $(\alpha)$} \\
\hline & & $\begin{array}{c}\text { Cattle } \\
\text { ranching } \\
\text { and } \\
\text { farming } \\
(1121)\end{array}$ & $\begin{array}{c}\text { Poultry } \\
\text { and egg } \\
\text { production } \\
(1123)\end{array}$ & $\begin{array}{l}\text { Aquaculture } \\
\text { and other } \\
\text { animals } \\
(112 X)\end{array}$ & $\begin{array}{c}\text { Animal } \\
\text { processing } \\
\text { except } \\
\text { poultry } \\
(31161 \mathrm{~A})\end{array}$ & $\begin{array}{l}\text { Poultry } \\
\text { processing } \\
\text { (311615) }\end{array}$ & $\begin{array}{l}\text { Seafood } \\
\text { processing } \\
(3117)\end{array}$ & $\begin{array}{c}\text { Grocery } \\
\text { wholesalers } \\
(4244)\end{array}$ & $\begin{array}{c}\text { Food and } \\
\text { beverage } \\
\text { retailers } \\
(445)\end{array}$ \\
\hline 111 & Crop production & 0.1401 & 0.0591 & 0.0273 & 0.0000 & 0.0000 & 0.0000 & 0.0001 & 0.0191 \\
\hline 112 & Animal production & 0.4861 & 0.1277 & 0.4358 & 0.7035 & 0.6296 & 0.1101 & 0.0109 & 0.0018 \\
\hline 114 & $\begin{array}{l}\text { Fishing, hunting } \\
\text { and trapping }\end{array}$ & 0.0000 & 0.0000 & 0.0000 & 0.0032 & 0.0073 & 0.5886 & 0.0000 & 0.0102 \\
\hline 115 & $\begin{array}{l}\text { Support activities } \\
\text { for agriculture } \\
\text { and forestry }\end{array}$ & 0.0245 & 0.0161 & 0.0366 & 0.0000 & 0.0000 & 0.0000 & 0.0000 & 0.0000 \\
\hline 211 & $\begin{array}{l}\text { Oil and gas extrac- } \\
\text { tion }\end{array}$ & 0.0000 & 0.0000 & 0.0000 & 0.0000 & 0.0000 & 0.0000 & 0.0001 & 0.0001 \\
\hline 212 & $\begin{array}{l}\text { Mining (except oil } \\
\text { and gas) }\end{array}$ & 0.0012 & 0.0244 & 0.0037 & 0.0012 & 0.0015 & 0.0058 & 0.0001 & 0.0000 \\
\hline 221 & Utilities & 0.0073 & 0.0101 & 0.0111 & 0.0067 & 0.0134 & 0.0134 & 0.0395 & 0.1126 \\
\hline 236 & $\begin{array}{l}\text { Nonresidential } \\
\text { maintenance } \\
\text { and repair }\end{array}$ & 0.0000 & 0.0018 & 0.0087 & 0.0010 & 0.0012 & 0.0020 & 0.0032 & 0.0071 \\
\hline 311 & $\begin{array}{l}\text { Food manufactur- } \\
\text { ing }\end{array}$ & 0.1525 & 0.6639 & 0.2885 & 0.2353 & 0.2104 & 0.0965 & 0.0015 & 0.0453 \\
\hline 312 & Breweries & 0.0000 & 0.0061 & 0.0035 & 0.0000 & 0.0000 & 0.0000 & 0.0000 & 0.0022 \\
\hline 314 & $\begin{array}{l}\text { Other textile prod- } \\
\text { uct mills }\end{array}$ & 0.0004 & 0.0000 & 0.0000 & 0.0000 & 0.0000 & 0.0000 & 0.0029 & 0.0027 \\
\hline 315 & $\begin{array}{l}\text { Apparel } \\
\text { manufacturing }\end{array}$ & 0.0000 & 0.0000 & 0.0000 & 0.0000 & 0.0000 & 0.0000 & 0.0000 & 0.0000 \\
\hline 316 & $\begin{array}{l}\text { Leather and allied } \\
\text { product } \\
\text { manufacturing }\end{array}$ & 0.0001 & 0.0000 & 0.0025 & 0.0000 & 0.0005 & 0.0000 & 0.0018 & 0.0001 \\
\hline 321 & $\begin{array}{l}\text { Wood product } \\
\text { manufacturing }\end{array}$ & 0.0001 & 0.0001 & 0.0001 & 0.0000 & 0.0000 & 0.0000 & 0.0057 & 0.0068 \\
\hline 322 & $\begin{array}{l}\text { Paper manufactur- } \\
\text { ing }\end{array}$ & 0.0000 & 0.0004 & 0.0000 & 0.0093 & 0.0291 & 0.0215 & 0.0148 & 0.0184 \\
\hline 323 & Printing & 0.0001 & 0.0000 & 0.0000 & 0.0000 & 0.0000 & 0.0000 & 0.0148 & 0.0034 \\
\hline 324 & $\begin{array}{l}\text { Petroleum and } \\
\text { coal products } \\
\text { manufacturing }\end{array}$ & 0.0389 & 0.0248 & 0.0311 & 0.0011 & 0.0016 & 0.0075 & 0.0186 & 0.0112 \\
\hline 325 & $\begin{array}{l}\text { Chemical } \\
\text { manufacturing }\end{array}$ & 0.0180 & 0.0163 & 0.0209 & 0.0003 & 0.0023 & 0.0010 & 0.0050 & 0.0009 \\
\hline 326 & $\begin{array}{l}\text { Plastics and rubber } \\
\text { product } \\
\text { manufacturing }\end{array}$ & 0.0029 & 0.0002 & 0.0030 & 0.0060 & 0.0227 & 0.0073 & 0.0450 & 0.0274 \\
\hline 327 & $\begin{array}{l}\text { Nonmetallic min- } \\
\text { eral product } \\
\text { manufacturing }\end{array}$ & 0.0000 & 0.0000 & 0.0000 & 0.0000 & 0.0000 & 0.0000 & 0.0005 & 0.0011 \\
\hline 331 & $\begin{array}{l}\text { Primary metal } \\
\text { manufacturing }\end{array}$ & 0.0004 & 0.0001 & 0.0001 & 0.0000 & 0.0000 & 0.0000 & 0.0000 & 0.0000 \\
\hline
\end{tabular}

(Continued) 
Table A1. (Continued)

\begin{tabular}{|c|c|c|c|c|c|c|c|c|c|}
\hline \multirow[b]{2}{*}{ NAICS } & \multirow[b]{2}{*}{$\begin{array}{l}\text { Industry } \\
\text { description }\end{array}$} & \multicolumn{8}{|c|}{ Input weights $(\alpha)$} \\
\hline & & $\begin{array}{l}\text { Cattle } \\
\text { ranching } \\
\text { and } \\
\text { farming } \\
(1121)\end{array}$ & $\begin{array}{l}\text { Poultry } \\
\text { and egg } \\
\text { production } \\
\text { (1123) }\end{array}$ & $\begin{array}{l}\text { Aquaculture } \\
\text { and other } \\
\text { animals } \\
(112 X)\end{array}$ & $\begin{array}{l}\text { Animal } \\
\text { processing } \\
\text { except } \\
\text { poultry } \\
(31161 \mathrm{~A})\end{array}$ & $\begin{array}{l}\text { Poultry } \\
\text { processing } \\
(311615)\end{array}$ & $\begin{array}{l}\text { Seafood } \\
\text { processing } \\
(3117)\end{array}$ & $\begin{array}{c}\text { Grocery } \\
\text { wholesalers } \\
(4244)\end{array}$ & $\begin{array}{c}\text { Food and } \\
\text { beverage } \\
\text { retailers } \\
(445)\end{array}$ \\
\hline 332 & $\begin{array}{l}\text { Fabricated metal } \\
\text { product } \\
\text { manufacturing }\end{array}$ & 0.0206 & 0.0010 & 0.0020 & 0.0006 & 0.0035 & 0.0047 & 0.0044 & 0.0028 \\
\hline 333 & $\begin{array}{l}\text { Machinery } \\
\text { manufacturing }\end{array}$ & 0.0074 & 0.0018 & 0.0208 & 0.0001 & 0.0002 & 0.0006 & 0.0041 & 0.0017 \\
\hline 334 & $\begin{array}{l}\text { Computer and } \\
\text { electronic prod- } \\
\text { uct manufactur- } \\
\text { ing }\end{array}$ & 0.0000 & 0.0000 & 0.0000 & 0.0002 & 0.0007 & 0.0007 & 0.0004 & 0.0042 \\
\hline 335 & $\begin{array}{l}\text { Electrical equip- } \\
\text { ment, appliance, } \\
\text { and component } \\
\text { manufacturing }\end{array}$ & 0.0000 & 0.0004 & 0.0049 & 0.0003 & 0.0015 & 0.0000 & 0.0011 & 0.0006 \\
\hline 336 & $\begin{array}{l}\text { Transportation } \\
\text { equipment } \\
\text { manufacturing }\end{array}$ & 0.0012 & 0.0003 & 0.0035 & 0.0003 & 0.0055 & 0.0002 & 0.0227 & 0.0193 \\
\hline 337 & $\begin{array}{l}\text { Furniture and } \\
\text { related product } \\
\text { manufacturing }\end{array}$ & 0.0000 & 0.0000 & 0.0000 & 0.0000 & 0.0000 & 0.0000 & 0.0044 & 0.0000 \\
\hline 339 & $\begin{array}{l}\text { All other miscella- } \\
\text { neous } \\
\text { manufacturing }\end{array}$ & 0.0038 & 0.0001 & 0.0000 & 0.0000 & 0.0000 & 0.0000 & 0.0049 & 0.0018 \\
\hline 423 & $\begin{array}{l}\text { Merchant whole- } \\
\text { salers, durable } \\
\text { goods }\end{array}$ & 0.0000 & 0.0000 & 0.0000 & 0.0000 & 0.0000 & 0.0000 & 0.0090 & 0.0010 \\
\hline 424 & $\begin{array}{l}\text { Other nondurable } \\
\text { goods merchant } \\
\text { wholesalers }\end{array}$ & 0.0000 & 0.0004 & 0.0000 & 0.0004 & 0.0007 & 0.0121 & 0.0146 & 0.0016 \\
\hline 425 & $\begin{array}{l}\text { Wholesale elec- } \\
\text { tronic markets } \\
\text { and agents and } \\
\text { brokers }\end{array}$ & 0.0039 & 0.0001 & 0.0094 & 0.0001 & 0.0003 & 0.0008 & 0.0093 & 0.0013 \\
\hline 481 & Air transportation & 0.0000 & 0.0000 & 0.0000 & 0.0008 & 0.0011 & 0.0013 & 0.0033 & 0.0005 \\
\hline 482 & Rail transportation & 0.0000 & 0.0000 & 0.0000 & 0.0000 & 0.0000 & 0.0000 & 0.0001 & 0.0001 \\
\hline 483 & $\begin{array}{l}\text { Water transporta- } \\
\text { tion }\end{array}$ & 0.0000 & 0.0000 & 0.0000 & 0.0000 & 0.0000 & 0.0000 & 0.0000 & 0.0000 \\
\hline 484 & $\begin{array}{l}\text { Truck transporta- } \\
\text { tion }\end{array}$ & 0.0000 & 0.0012 & 0.0011 & 0.0000 & 0.0000 & 0.0000 & 0.0040 & 0.0148 \\
\hline 485 & $\begin{array}{l}\text { Transit and ground } \\
\text { passenger trans- } \\
\text { portation }\end{array}$ & 0.0000 & 0.0000 & 0.0000 & 0.0002 & 0.0003 & 0.0003 & 0.0012 & 0.0001 \\
\hline 487 & $\begin{array}{l}\text { Scenic and sight- } \\
\text { seeing transpor- } \\
\text { tation and } \\
\text { support activi- } \\
\text { ties for trans- } \\
\text { portation }\end{array}$ & 0.0000 & 0.0000 & 0.0000 & 0.0000 & 0.0000 & 0.0047 & 0.0231 & 0.0032 \\
\hline 492 & $\begin{array}{l}\text { Couriers and mes- } \\
\text { sengers }\end{array}$ & 0.0000 & 0.0000 & 0.0000 & 0.0000 & 0.0000 & 0.0000 & 0.0451 & 0.0061 \\
\hline 493 & $\begin{array}{l}\text { Warehousing and } \\
\text { storage }\end{array}$ & 0.0003 & 0.0006 & 0.0018 & 0.0001 & 0.0003 & 0.0006 & 0.0434 & 0.1245 \\
\hline
\end{tabular}


Table A1. (Continued)

\begin{tabular}{|c|c|c|c|c|c|c|c|c|c|}
\hline \multirow[b]{2}{*}{ NAICS } & \multirow[b]{2}{*}{$\begin{array}{l}\text { Industry } \\
\text { description }\end{array}$} & \multicolumn{8}{|c|}{ Input weights $(\alpha)$} \\
\hline & & $\begin{array}{l}\text { Cattle } \\
\text { ranching } \\
\text { and } \\
\text { farming } \\
(1121)\end{array}$ & $\begin{array}{c}\text { Poultry } \\
\text { and egg } \\
\text { production } \\
(1123)\end{array}$ & $\begin{array}{l}\text { Aquaculture } \\
\text { and other } \\
\text { animals } \\
(112 \mathrm{X})\end{array}$ & $\begin{array}{l}\text { Animal } \\
\text { processing } \\
\text { except } \\
\text { poultry } \\
(31161 \mathrm{~A})\end{array}$ & $\begin{array}{c}\text { Poultry } \\
\text { processing } \\
(311615)\end{array}$ & $\begin{array}{c}\text { Seafood } \\
\text { processing } \\
(3117)\end{array}$ & $\begin{array}{c}\text { Grocery } \\
\text { wholesalers } \\
(4244)\end{array}$ & $\begin{array}{c}\text { Food and } \\
\text { beverage } \\
\text { retailers } \\
(445)\end{array}$ \\
\hline 511 & $\begin{array}{l}\text { Publishing indus- } \\
\text { tries (except } \\
\text { internet) }\end{array}$ & 0.0000 & 0.0001 & 0.0001 & 0.0000 & 0.0000 & 0.0000 & 0.0010 & 0.0028 \\
\hline 512 & $\begin{array}{l}\text { Motion picture and } \\
\text { sound recording } \\
\text { industries }\end{array}$ & 0.0000 & 0.0000 & 0.0000 & 0.0000 & 0.0000 & 0.0000 & 0.0000 & 0.0025 \\
\hline 517 & $\begin{array}{l}\text { Telecommunicatio- } \\
\text { ns }\end{array}$ & 0.0017 & 0.0020 & 0.0025 & 0.0007 & 0.0012 & 0.0022 & 0.0165 & 0.0090 \\
\hline 518 & $\begin{array}{l}\text { Data processing, } \\
\text { hosting, and } \\
\text { related services }\end{array}$ & 0.0000 & 0.0000 & 0.0000 & 0.0006 & 0.0013 & 0.0016 & 0.0041 & 0.0098 \\
\hline 519 & $\begin{array}{l}\text { Other information } \\
\text { services }\end{array}$ & 0.0000 & 0.0000 & 0.0000 & 0.0000 & 0.0000 & 0.0000 & 0.0000 & 0.0034 \\
\hline 521 & $\begin{array}{l}\text { Monetary authori- } \\
\text { ties and deposi- } \\
\text { tory credit } \\
\text { intermediation }\end{array}$ & 0.0038 & 0.0007 & 0.0036 & 0.0011 & 0.0029 & 0.0058 & 0.0211 & 0.0141 \\
\hline 522 & $\begin{array}{l}\text { Nondepository } \\
\text { credit intermedi- } \\
\text { ation and } \\
\text { related activities }\end{array}$ & 0.0001 & 0.0004 & 0.0018 & 0.0006 & 0.0010 & 0.0024 & 0.0221 & 0.0297 \\
\hline 523 & $\begin{array}{l}\text { Securities, com- } \\
\text { modity con- } \\
\text { tracts, and } \\
\text { other financial } \\
\text { investments }\end{array}$ & 0.0031 & 0.0002 & 0.0004 & 0.0002 & 0.0005 & 0.0007 & 0.0029 & 0.0032 \\
\hline 524 & $\begin{array}{l}\text { Insurance carriers } \\
\text { and related } \\
\text { activities }\end{array}$ & 0.0015 & 0.0044 & 0.0113 & 0.0002 & 0.0006 & 0.0027 & 0.0168 & 0.0122 \\
\hline 531 & Other real estate & 0.0649 & 0.0102 & 0.0376 & 0.0008 & 0.0005 & 0.0033 & 0.0615 & 0.1711 \\
\hline 532 & $\begin{array}{l}\text { Rental and leasing } \\
\text { services }\end{array}$ & 0.0069 & 0.0044 & 0.0062 & 0.0006 & 0.0011 & 0.0016 & 0.0441 & 0.0065 \\
\hline 533 & $\begin{array}{l}\text { Lessors of nonfi- } \\
\text { nancial intangi- } \\
\text { ble assets }\end{array}$ & 0.0000 & 0.0000 & 0.0000 & 0.0009 & 0.0019 & 0.0035 & 0.0165 & 0.0129 \\
\hline 541 & $\begin{array}{l}\text { Professional, scien- } \\
\text { tific, and techni- } \\
\text { cal services }\end{array}$ & 0.0038 & 0.0154 & 0.0130 & 0.0060 & 0.0084 & 0.0317 & 0.1218 & 0.1058 \\
\hline 550 & $\begin{array}{l}\text { Management of } \\
\text { companies and } \\
\text { enterprises }\end{array}$ & 0.0000 & 0.0000 & 0.0000 & 0.0112 & 0.0364 & 0.0524 & 0.1663 & 0.0465 \\
\hline 561 & $\begin{array}{l}\text { Administrative and } \\
\text { support services }\end{array}$ & 0.0016 & 0.0016 & 0.0021 & 0.0020 & 0.0028 & 0.0043 & 0.0752 & 0.0408 \\
\hline 562 & $\begin{array}{l}\text { Waste manage- } \\
\text { ment and reme- } \\
\text { diation services }\end{array}$ & 0.0008 & 0.0009 & 0.0007 & 0.0010 & 0.0031 & 0.0018 & 0.0033 & 0.0066 \\
\hline 611 & $\begin{array}{l}\text { Educational serv- } \\
\text { ices }\end{array}$ & 0.0000 & 0.0000 & 0.0001 & 0.0000 & 0.0000 & 0.0000 & 0.0009 & 0.0147 \\
\hline 711 & $\begin{array}{l}\text { Performing arts, } \\
\text { spectator } \\
\text { sports, and } \\
\text { related indus- } \\
\text { tries }\end{array}$ & 0.0000 & 0.0001 & 0.0003 & 0.0001 & 0.0002 & 0.0002 & 0.0024 & 0.0063 \\
\hline
\end{tabular}


Table A1. (Continued)

\begin{tabular}{|c|c|c|c|c|c|c|c|c|c|}
\hline \multirow[b]{2}{*}{ NAICS } & \multirow[b]{2}{*}{$\begin{array}{l}\text { Industry } \\
\text { description }\end{array}$} & \multicolumn{8}{|c|}{ Input weights $(\alpha)$} \\
\hline & & $\begin{array}{l}\text { Cattle } \\
\text { ranching } \\
\text { and } \\
\text { farming } \\
(1121)\end{array}$ & $\begin{array}{l}\text { Poultry } \\
\text { and egg } \\
\text { production } \\
(1123)\end{array}$ & $\begin{array}{l}\text { Aquaculture } \\
\text { and other } \\
\text { animals } \\
(112 \mathrm{X})\end{array}$ & $\begin{array}{c}\text { Animal } \\
\text { processing } \\
\text { except } \\
\text { poultry } \\
(31161 \mathrm{~A})\end{array}$ & $\begin{array}{c}\text { Poultry } \\
\text { processing } \\
(311615)\end{array}$ & $\begin{array}{l}\text { Seafood } \\
\text { processing } \\
(3117)\end{array}$ & $\begin{array}{c}\text { Grocery } \\
\text { wholesalers } \\
(4244)\end{array}$ & $\begin{array}{c}\text { Food and } \\
\text { beverage } \\
\text { retailers } \\
(445)\end{array}$ \\
\hline 713 & $\begin{array}{l}\text { Other amusement } \\
\text { and recreation } \\
\text { industries }\end{array}$ & 0.0000 & 0.0001 & 0.0002 & 0.0000 & 0.0000 & 0.0000 & 0.0010 & 0.0006 \\
\hline 721 & Accommodation & 0.0000 & 0.0000 & 0.0000 & 0.0005 & 0.0007 & 0.0008 & 0.0018 & 0.0009 \\
\hline 722 & $\begin{array}{l}\text { Food service and } \\
\text { drinking places }\end{array}$ & 0.0017 & 0.0016 & 0.0017 & 0.0007 & 0.0012 & 0.0015 & 0.0084 & 0.0115 \\
\hline 811 & $\begin{array}{l}\text { Repair and mainte- } \\
\text { nance }\end{array}$ & 0.0000 & 0.0002 & 0.0016 & 0.0018 & 0.0022 & 0.0035 & 0.0456 & 0.0334 \\
\hline 812 & $\begin{array}{l}\text { Personal and laun- } \\
\text { dry services }\end{array}$ & 0.0000 & 0.0000 & 0.0000 & 0.0000 & 0.0000 & 0.0000 & 0.0048 & 0.0009 \\
\hline 813 & $\begin{array}{l}\text { Civic, social, pro- } \\
\text { fessional, and } \\
\text { similar organiza- } \\
\text { tions }\end{array}$ & 0.0001 & 0.0003 & 0.0004 & 0.0001 & 0.0002 & 0.0003 & 0.0026 & 0.0007 \\
\hline
\end{tabular}

Note: The " $X$ " in the header "Aquaculture \& Other Animals (112X)" refers to the final digit of the four-digit NAICS code for: Hog and pig farming (1122); Sheep and goat farming (1124); Aquaculture (1125); and Other animal production (1126). Each of these sectors are assumed to follow the same input weighting.

Note: The "A" in the header "Animal Processing Except Poultry (31161A)" refers to the final digit of the six-digit NAICS code for: Animal (except poultry) slaughtering (311611) ; Meat processed from carcasses (311612); and Rendering and meat byproduct processing (311613). Each of these sectors are assumed to follow the same input weighting. 
Table A2. Number of direct restrictions across animal protein value chains

\begin{tabular}{|c|c|c|c|c|c|c|c|c|c|}
\hline & $\begin{array}{l}\text { Cattle } \\
\text { ranching }\end{array}$ & $\begin{array}{l}\text { Hog and } \\
\text { pig }\end{array}$ & $\begin{array}{l}\text { Poultry } \\
\text { and egg }\end{array}$ & $\begin{array}{c}\text { Sheep and } \\
\text { goat }\end{array}$ & Aquaculture & $\begin{array}{c}\text { Other } \\
\text { animal }\end{array}$ & Processing & Wholesale & $\begin{array}{l}\text { Retail } \\
\text { sales }\end{array}$ \\
\hline NAICS & 1121 & 1122 & 1123 & 1124 & 1125 & 1129 & $311 X$ & 4244 & 4451 \\
\hline 1970 & 558 & 1,194 & 790 & 1,072 & 6,852 & 1,482 & 6,999 & 555 & 3,034 \\
\hline 1971 & 600 & 1,221 & 822 & 1,109 & 6,906 & 1,463 & 7,438 & 650 & 3,040 \\
\hline 1972 & 632 & 1,340 & 865 & 1,154 & 7,222 & 1,480 & 7,845 & 645 & 3,578 \\
\hline 1973 & 817 & 1,598 & 1,074 & 1,451 & 7,823 & 1,698 & 8,091 & 634 & 3,961 \\
\hline 1974 & 860 & 1,735 & 1,295 & 1,561 & 8,025 & 1,736 & 8,733 & 631 & 4,063 \\
\hline 1975 & 906 & 1,829 & 1,514 & 1,631 & 8,190 & 1,777 & 8,772 & 582 & 4,115 \\
\hline 1976 & 958 & 1,873 & 1,675 & 1,659 & 7,763 & 1,799 & 9,871 & 608 & 3,876 \\
\hline 1977 & 1,011 & 1,940 & 1,931 & 1,774 & 8,205 & 1,767 & 9,561 & 958 & 4,009 \\
\hline 1978 & 1,135 & 2,064 & 2,358 & 1,965 & 8,451 & 2,011 & 8,490 & 1,073 & 3,446 \\
\hline 1979 & 1,432 & 2,584 & 2,885 & 2,245 & 8,276 & 2,211 & 8,721 & 1,130 & 3,904 \\
\hline 1980 & 1,179 & 2,433 & 2,820 & 2,252 & 9,985 & 2,090 & 8,726 & 1,329 & 4,538 \\
\hline 1981 & 1,182 & 2,366 & 2,757 & 2,174 & 11,655 & 2,079 & 9,464 & 1,411 & 4,823 \\
\hline 1982 & 1,269 & 2,388 & 2,629 & 2,219 & 12,348 & 2,065 & 9,256 & 1,375 & 4,561 \\
\hline 1983 & 1,474 & 2,668 & 2,960 & 2,380 & 13,186 & 2,268 & 9,452 & 1,286 & 4,429 \\
\hline 1984 & 1,352 & 2,594 & 3,177 & 2,428 & 13,793 & 2,368 & 9,477 & 1,988 & 4,561 \\
\hline 1985 & 1,369 & 2,573 & 3,274 & 2,293 & 14,281 & 2,393 & 9,919 & 1,886 & 4,677 \\
\hline 1986 & 1,444 & 2,669 & 3,278 & 2,390 & 15,677 & 2,454 & 10,113 & 1,932 & 4,904 \\
\hline 1987 & 1,804 & 2,760 & 4,177 & 2,542 & 15,584 & 2,543 & 10,407 & 2,112 & 4,940 \\
\hline 1988 & 1,853 & 2,964 & 4,352 & 2,812 & 15,831 & 3,002 & 10,505 & 2,213 & 5,063 \\
\hline 1989 & 1,793 & 3,029 & 4,691 & 2,882 & 17,240 & 2,915 & 11,095 & 2,235 & 5,521 \\
\hline 1990 & 1,849 & 3,028 & 4,732 & 2,819 & 17,769 & 2,986 & 11,889 & 2,359 & 6,418 \\
\hline 1991 & 1,538 & 2,818 & 4,657 & 2,483 & 18,521 & 2,898 & 11,689 & 2,154 & 6,034 \\
\hline 1992 & 1,618 & 2,852 & 4,585 & 2,626 & 20,100 & 3,063 & 11,913 & 2,123 & 6,956 \\
\hline 1993 & 1,870 & 3,438 & 4,789 & 3,270 & 21,905 & 3,166 & 12,461 & 2,062 & 8,071 \\
\hline 1994 & 2,229 & 3,797 & 5,264 & 3,725 & 23,487 & 3,760 & 12,886 & 2,161 & 8,885 \\
\hline 1995 & 2,193 & 3,603 & 4,901 & 3,623 & 22,815 & 3,354 & 12,668 & 1,887 & 9,227 \\
\hline 1996 & 2,196 & 3,632 & 4,780 & 3,706 & 22,106 & 3,227 & 13,587 & 2,948 & 9,062 \\
\hline 1997 & 2,353 & 4,136 & 4,145 & 3,895 & 23,688 & 3,577 & 13,526 & 2,671 & 7,395 \\
\hline 1998 & 2,437 & 4,229 & 4,213 & 4,010 & 24,210 & 3,578 & 13,606 & 2,764 & 7,339 \\
\hline 1999 & 2,653 & 4,345 & 4,646 & 4,145 & 24,902 & 3,567 & 13,703 & 2,648 & 7,220 \\
\hline 2000 & 2,908 & 4,528 & 4,836 & 4,350 & 26,171 & 3,752 & 14,317 & 2,650 & 7,226 \\
\hline 2001 & 3,092 & 4,740 & 5,204 & 4,682 & 27,128 & 4,166 & 14,791 & 2,823 & 8,556 \\
\hline 2002 & 3,095 & 4,779 & 5,229 & 4,730 & 27,255 & 4,183 & 15,111 & 2,912 & 7,846 \\
\hline 2003 & 3,443 & 5,014 & 5,456 & 4,946 & 28,347 & 4,203 & 15,052 & 3,178 & 7,833 \\
\hline 2004 & 3,540 & 5,065 & 5,415 & 4,969 & 26,044 & 4,185 & 14,972 & 3,681 & 7,641 \\
\hline
\end{tabular}


Table A2. (Continued)

\begin{tabular}{|c|c|c|c|c|c|c|c|c|c|}
\hline & $\begin{array}{l}\text { Cattle } \\
\text { ranching }\end{array}$ & $\begin{array}{l}\text { Hog and } \\
\text { pig }\end{array}$ & $\begin{array}{l}\text { Poultry } \\
\text { and egg }\end{array}$ & $\begin{array}{c}\text { Sheep and } \\
\text { goat }\end{array}$ & Aquaculture & $\begin{array}{c}\text { Other } \\
\text { animal }\end{array}$ & Processing & Wholesale & $\begin{array}{c}\text { Retail } \\
\text { sales }\end{array}$ \\
\hline 2005 & 3,616 & 5,175 & 5,608 & 5,125 & 27,653 & 4,407 & 14,885 & 3,760 & 7,780 \\
\hline 2006 & 3,533 & 4,971 & 5,385 & 4,988 & 29,308 & 4,177 & 14,655 & 3,908 & 7,841 \\
\hline 2007 & 3,556 & 5,006 & 5,424 & 5,023 & 29,569 & 4,288 & 14,680 & 4,158 & 8,079 \\
\hline 2008 & 3,480 & 4,989 & 5,453 & 5,036 & 30,040 & 4,358 & 17,630 & 4,371 & 7,999 \\
\hline 2009 & 3,699 & 5,222 & 5,608 & 5,226 & 32,435 & 4,458 & 17,490 & 4,612 & 7,896 \\
\hline 2010 & 3,567 & 5,248 & 5,536 & 5,252 & 33,054 & 4,323 & 17,599 & 5,084 & 8,005 \\
\hline 2011 & 3,589 & 5,294 & 5,415 & 5,387 & 33,916 & 4,384 & 17,819 & 5,217 & 9,764 \\
\hline 2012 & 3,720 & 5,525 & 5,687 & 5,636 & 35,595 & 4,595 & 19,147 & 5,147 & 9,819 \\
\hline 2013 & 3,627 & 5,492 & 5,641 & 5,616 & 35,494 & 4,597 & 19,506 & 5,390 & 9,952 \\
\hline 2014 & 3,374 & 5,532 & 5,465 & 5,666 & 36,585 & 4,603 & 18,961 & 5,692 & 10,022 \\
\hline 2015 & 3,487 & 5,684 & 5,751 & 5,767 & 36,976 & 4,579 & 19,853 & 5,446 & 10,510 \\
\hline 2016 & 3,696 & 6,201 & 6,149 & 6,309 & 37,722 & 4,790 & 22,899 & 5,859 & 10,143 \\
\hline 2017 & 3,722 & 6,404 & 6,264 & 6,423 & 47,221 & 5,210 & 23,174 & 5,242 & 11,784 \\
\hline 2018 & 3,737 & 6,447 & 6,359 & 6,469 & 47,760 & 5,246 & 23,177 & 5,178 & 11,898 \\
\hline 2019 & 3,761 & 6,505 & 6,256 & 6,511 & 48,843 & 5,323 & 22,903 & 5,027 & 11,839 \\
\hline
\end{tabular}

Processing modeled using NAICS sectors 311611 to 311613,311615 , and 3117 . 
Table A3. Total number of direct and indirect restrictions across animal protein value chains

\begin{tabular}{|c|c|c|c|c|c|c|c|c|c|}
\hline & $\begin{array}{l}\text { Cattle } \\
\text { ranching }\end{array}$ & $\begin{array}{l}\text { Hog and } \\
\text { pig }\end{array}$ & $\begin{array}{l}\text { Poultry } \\
\text { and egg }\end{array}$ & $\begin{array}{c}\text { Sheep and } \\
\text { goat }\end{array}$ & Aquaculture & $\begin{array}{l}\text { Other } \\
\text { animal }\end{array}$ & Processing & Wholesale & $\begin{array}{l}\text { Retail } \\
\text { sales }\end{array}$ \\
\hline NAICS & 1121 & 1122 & 1123 & 1124 & 1125 & 1129 & $311 \mathrm{X}$ & 4244 & 4451 \\
\hline 1970 & 7,726 & 8,905 & 9,651 & 8,783 & 14,563 & 9,194 & 27,844 & 5,730 & 8,133 \\
\hline 1971 & 7,969 & 8,843 & 9,245 & 8,731 & 14,528 & 9,086 & 28,273 & 6,456 & 8,732 \\
\hline 1972 & 7,717 & 8,776 & 9,573 & 8,590 & 14,658 & 8,915 & 28,242 & 7,685 & 10,363 \\
\hline 1973 & 8,265 & 9,255 & 9,715 & 9,108 & 15,481 & 9,356 & 29,205 & 7,993 & 11,031 \\
\hline 1974 & 8,877 & 9,900 & 10,176 & 9,725 & 16,190 & 9,901 & 31,652 & 8,534 & 11,653 \\
\hline 1975 & 9,628 & 11,069 & 12,304 & 10,871 & 17,430 & 11,017 & 34,078 & 9,419 & 12,633 \\
\hline 1976 & 9,839 & 11,299 & 12,577 & 11,084 & 17,189 & 11,224 & 35,789 & 9,920 & 12,801 \\
\hline 1977 & 10,016 & 11,357 & 12,044 & 11,191 & 17,622 & 11,183 & 36,114 & 11,086 & 13,508 \\
\hline 1978 & 11,083 & 12,074 & 12,482 & 11,975 & 18,461 & 12,020 & 37,091 & 11,387 & 13,114 \\
\hline 1979 & 11,433 & 12,733 & 13,717 & 12,395 & 18,425 & 12,361 & 37,232 & 11,893 & 13,991 \\
\hline 1980 & 11,820 & 13,153 & 13,609 & 12,972 & 20,706 & 12,810 & 39,262 & 12,780 & 15,341 \\
\hline 1981 & 11,964 & 13,486 & 13,758 & 13,293 & 22,774 & 13,199 & 41,429 & 14,268 & 16,926 \\
\hline 1982 & 12,760 & 14,174 & 14,114 & 14,005 & 24,134 & 13,851 & 43,324 & 14,375 & 16,835 \\
\hline 1983 & 12,986 & 14,431 & 14,407 & 14,143 & 24,950 & 14,032 & 43,364 & 13,741 & 16,243 \\
\hline 1984 & 13,155 & 14,757 & 14,982 & 14,590 & 25,956 & 14,531 & 44,249 & 16,295 & 17,824 \\
\hline 1985 & 13,000 & 14,430 & 15,278 & 14,151 & 26,138 & 14,250 & 43,914 & 14,780 & 16,957 \\
\hline 1986 & 13,787 & 15,220 & 15,521 & 14,941 & 28,228 & 15,004 & 46,132 & 15,099 & 17,471 \\
\hline 1987 & 15,048 & 16,195 & 17,126 & 15,977 & 29,019 & 15,978 & 48,981 & 15,898 & 18,067 \\
\hline 1988 & 15,219 & 16,487 & 17,371 & 16,335 & 29,354 & 16,526 & 49,113 & 16,845 & 18,949 \\
\hline 1989 & 15,715 & 16,987 & 17,830 & 16,840 & 31,198 & 16,873 & 51,131 & 18,189 & 20,483 \\
\hline 1990 & 16,230 & 17,376 & 18,098 & 17,168 & 32,118 & 17,334 & 53,027 & 19,040 & 21,934 \\
\hline 1991 & 16,153 & 17,475 & 18,268 & 17,140 & 33,179 & 17,556 & 53,713 & 18,946 & 21,703 \\
\hline 1992 & 17,262 & 18,473 & 18,664 & 18,247 & 35,721 & 18,683 & 56,979 & 19,134 & 22,774 \\
\hline 1993 & 18,233 & 19,558 & 18,943 & 19,391 & 38,025 & 19,286 & 58,755 & 18,999 & 23,626 \\
\hline 1994 & 20,280 & 21,948 & 21,724 & 21,876 & 41,638 & 21,912 & 63,931 & 20,380 & 25,752 \\
\hline 1995 & 20,685 & 22,227 & 21,715 & 22,247 & 41,439 & 21,978 & 64,854 & 20,278 & 26,231 \\
\hline 1996 & 19,751 & 21,345 & 20,874 & 21,419 & 39,819 & 20,941 & 62,612 & 20,302 & 25,416 \\
\hline 1997 & 20,231 & 22,051 & 20,084 & 21,810 & 41,604 & 21,492 & 63,017 & 21,916 & 25,330 \\
\hline 1998 & 20,915 & 22,628 & 20,324 & 22,408 & 42,608 & 21,976 & 64,907 & 21,804 & 25,162 \\
\hline 1999 & 21,889 & 23,380 & 21,094 & 23,180 & 43,936 & 22,602 & 66,167 & 21,659 & 25,037 \\
\hline 2000 & 22,055 & 22,753 & 18,404 & 22,575 & 44,397 & 21,977 & 65,499 & 21,914 & 25,047 \\
\hline 2001 & 23,365 & 23,784 & 18,935 & 23,726 & 46,172 & 23,210 & 68,282 & 22,533 & 26,758 \\
\hline 2002 & 23,880 & 24,323 & 19,369 & 24,274 & 46,799 & 23,727 & 69,462 & 23,168 & 26,489 \\
\hline 2003 & 24,407 & 24,779 & 19,741 & 24,712 & 48,112 & 23,968 & 69,374 & 23,581 & 26,581 \\
\hline 2004 & 22,369 & 22,888 & 18,968 & 22,792 & 43,867 & 22,007 & 63,655 & 23,827 & 26,131 \\
\hline
\end{tabular}


Table A3. (Continued)

\begin{tabular}{|c|c|c|c|c|c|c|c|c|c|}
\hline & $\begin{array}{l}\text { Cattle } \\
\text { ranching }\end{array}$ & $\begin{array}{l}\text { Hog and } \\
\text { pig }\end{array}$ & $\begin{array}{l}\text { Poultry } \\
\text { and egg }\end{array}$ & $\begin{array}{c}\text { Sheep and } \\
\text { goat }\end{array}$ & Aquaculture & $\begin{array}{l}\text { Other } \\
\text { animal }\end{array}$ & Processing & Wholesale & $\begin{array}{l}\text { Retail } \\
\text { sales }\end{array}$ \\
\hline 2005 & 22,811 & 23,338 & 19,265 & 23,288 & 45,816 & 22,570 & 64,838 & 24,154 & 26,525 \\
\hline 2006 & 23,682 & 24,048 & 19,402 & 24,065 & 48,385 & 23,254 & 66,832 & 24,582 & 26,871 \\
\hline 2007 & 23,538 & 24,010 & 19,565 & 24,027 & 48,573 & 23,292 & 66,778 & 25,277 & 27,606 \\
\hline 2008 & 24,066 & 24,557 & 20,125 & 24,605 & 49,609 & 23,927 & 71,110 & 25,920 & 27,902 \\
\hline 2009 & 25,108 & 25,553 & 20,645 & 25,557 & 52,766 & 24,789 & 73,321 & 26,560 & 28,149 \\
\hline 2010 & 25,412 & 25,985 & 20,724 & 25,989 & 53,791 & 25,059 & 74,968 & 27,215 & 28,419 \\
\hline 2011 & 26,142 & 26,761 & 21,132 & 26,854 & 55,383 & 25,850 & 76,792 & 28,523 & 31,507 \\
\hline 2012 & 27,530 & 28,286 & 22,446 & 28,397 & 58,356 & 27,356 & 81,845 & 29,097 & 32,477 \\
\hline 2013 & 28,119 & 28,931 & 22,792 & 29,055 & 58,934 & 28,037 & 83,737 & 30,036 & 34,160 \\
\hline 2014 & 28,134 & 29,184 & 22,798 & 29,318 & 60,237 & 28,255 & 83,626 & 31,125 & 35,523 \\
\hline 2015 & 28,848 & 29,889 & 23,382 & 29,972 & 61,180 & 28,784 & 86,180 & 30,475 & 35,490 \\
\hline 2016 & 29,076 & 30,529 & 24,331 & 30,637 & 62,050 & 29,118 & 88,023 & 31,513 & 35,780 \\
\hline 2017 & 36,474 & 37,269 & 26,937 & 37,288 & 78,086 & 36,075 & 108,167 & 32,120 & 38,899 \\
\hline 2018 & 36,519 & 37,328 & 27,050 & 37,349 & 78,640 & 36,127 & 108,033 & 31,941 & 38,960 \\
\hline 2019 & 36,515 & 37,435 & 26,526 & 37,441 & 79,773 & 36,253 & 108,045 & 31,732 & 38,742 \\
\hline
\end{tabular}

Processing modeled using NAICS sectors 311611 to 311613,311615 , and 3117 .

Cite this article: Staples, A.J., D. Chambers, R.T. Melstrom, and T. Malone (2022). "Regulatory Restrictions Across U.S. Protein Supply Chains." Journal of Agricultural and Applied Economics 54, 1-27. https://doi.org/10.1017/aae.2021.28 